\title{
Neo-Latin Drama in the Low Countries
}

\author{
Jan Bloemendal
}

The Low Countries as a Historical, Religious and Literary Melting Pot

Between c. 1500 and 1750 some hundreds of Latin plays were written, staged and printed in the Low Countries from St. Omaars to Leeuwarden. ${ }^{1}$ Some of them had a huge international resonance, witness many editions and performances all over Europe. In the selection of ten representative biblical dramas printed by Nicolaus Brylinger in Basel, 1541, seven of them were written by authors from the Low Countries which were a leading region in drama in the sixteenth century. However, speaking of the 'Low Countries' involves some geographical difficulties. The early modern territory encompassed roughly the area that now comprises the Netherlands, Belgium, Luxemburg, small parts of Germany and some parts of northern France. ${ }^{2}$ The area was divided into rather autonomous provinces, while the cities had their own forms of autonomy. The rulers confirmed their dominion by magnificent 'Joyous Entries' ('Blijde Intredes') in the cities, mainly in the southern provinces that formed the economic heart in the beginning of the sixteenth century. The Low Countries with their approximately 2.5 million inhabitants were highly urbanised.

The protestant Reformation that starting with Martin Luther in the 1510s and 1520s would 'divide Europe's House', also divided the Habsburg rulers and the Low Countries. While both parties had conflicting interests and conflicting religious convictions, Emperor Charles V (15001558) and his successor Philip II (1527-1598) tried to stop the spread of 'heretic' ideas by confining the autonomy of the provinces and the cities. As a consequence, the rulers had to deal with not only religious dissidence, but also with political rebellion. In these quarrels, literature written by Rhetoricians took a prominent role. Their Chambers were a place of discussion and exchange of ideas and according to the authorities potential centres of dissidence. The central power reacted vehemently with Edicts and other proclamations against them and against the spread of ideas through the printing press, that was a forceful agent in spreading the Reformation. $^{3}$

The Low Countries' government, comprising of the States General (a collective representative body of the provinces and the main cities) and the 'Stadtholder' (representative of the king) William the Silent (1533-1584), reacted by the 'Dutch Revolt' from 1568 onwards, and the 'Act of Abjuration' in 1581. These eventually caused a division of the Low Countries: six southern provinces, Hainault, Artois, Walloon Flanders, Tournai, Namur, Luxembourg and Limburg,

\footnotetext{
${ }^{1}$ See for a list of Dutch plays IJsewijn, 'Annales Theatri Belgo-Latini'. The Low Countries were called 'a main region for Latin drama’ by, for instance, Creizenach, Geschichte des neueren Dramas, 2, p. 70, 83. In Germany, however, religious drama was written long after a series of plays was published by Dutch, ibidem, p. 71 .

${ }^{2}$ For the historical backgrounds I based myself on Blockmans and Prevenier, The Burgundian Netherlands, Duke, Reformation and Revolt in the Low Countries, Parker, The Dutch Revolt, Israel, The Dutch Republic, MacCulloch, The Reformation and the introduction by Strietman and Happé in idem, Urban Theatre in the Low Countries, pp. 1-33, esp. 124.

${ }^{3}$ See, e.g., Eisenstein, The Printing Press as an Agent of Change. As she also acknowledges, besides the printed word, the spoken one was important in spreading reformatory ideas.
} 
submitted themselves again to Philip's authority and returned to Catholicism, while the Northern provinces Zeeland, Holland, Utrecht and part of Gelderland separated and became the Protestant Dutch Republic. Many Protestants from the south, including Rhetoricians and humanists, fled to the Northern provinces. The 'Dutch Revolt', which became the 'Eighty Years' War', would last until 1648.

The years of war and religious strife did not prevent economic growth of parts of the Low Countries; in fact they advanced it. One of the major events was the Fall of Antwerp, 1585, when the city was conquered by the Spaniards. This caused the moving of the economic centre from 'south' to 'north' and the rise of Amsterdam as a trading centre. Economic success is a good basis for cultural blossoming, and the Low Countries became and remained a region of much cultural activity, in painting, music, literature and humanistic learning.

Both Latin schools and universities were centres of humanism. The Low Countries had two universities. The first one was the University of Leuven, founded in 1425, that initially had a medieval, scholastic spirit, but gradually became a centre of renewal. In 1518 Erasmus was one of the founders of the Collegium trilingue or 'Collegie der drie Tonghen' (where 'the' three languages, Latin, Greek and Hebrew were taught) in the same city. ${ }^{4}$ In 1575, the Northern provinces established their own university, at Leiden, which became a heart of humanism and Calvinism, and of literary renewal.

In these changing circumstances, from the beginnings of the sixteenth century the highly urbanised Low Countries, that had already been a 'theatre state' or even a 'theatre society' in the fifteenth century, ${ }^{5}$ saw a relatively short, but intense blossoming of Latin drama. The first plays were performed in the first decades of the sixteenth century, and around 1650 there was a decline, at least in the Northern provinces. In these decades they were, together with Germany, a leading region in Latin drama. This shift may partly be connected with the fact that many humanists did not yet strive for a literature in the vernacular in the sense of Renaissance poetics. In the southern part Latin drama survived for a longer period. This difference was partly a result of the division of the Low Countries between the (northern) Republic of the United Netherlands and the (southern) Habsburg provinces already mentioned.

One remark still has to be made. Often Dutch Latin drama is seen as a part of German drama. ${ }^{6}$ Viewed in the light of the humanists' inspiration, there are grounds for that. But the Low Countries certainly had their own developments and merits, and some plays were extremely successful abroad, and by then seen as products from the Low Countries. Nevertheless, there was a lively interaction between the Low Countries and the Upper Germanic lands.

\section{The Origins of Latin Drama in the Low Countries}

From the last decades of the fifteenth and the first decade of the sixteenth century Latin plays were performed in the universities, in the schools, in town halls, or at market places. This custom started in the southern provinces, in the $1480 \mathrm{~s}^{7}$ For instance, in October of 1484 book 1 of

\footnotetext{
${ }^{4}$ On the history of the Collegium trilignue, see De Vocht, History of the Foundation and the Rise of the Collegium trilingue. As a matter of fact, the Collegium inspired King of France Francis I to establish the 'Collège de France' (1530).

${ }^{5}$ Arnade, Realms of Ritual, and Van Dixhoorn, 'Theatre society in the Early Modern Low Countries', resp.

${ }^{6}$ So, for instance, Roloff, 'Neulateinisches Drama'; Parente, Religious Drama and the Humanist Tradition.

7 IJsewijn, ‘Theatrum Belgo-Latinum', p. 80.
} 
Virgil's Aeneid was staged in Bruges. ${ }^{8}$ Probably, these epic texts were recited by several students. In the same year a Declamatio had been acted in Leuven: a debate about the strictness of some regulations that students of law had to observe. For instance, they had to attend lectures on poetica. The opponent replies that a lawyer can only do his job if he has some of the fluency that poetry provides. In the city of Leuven important centres of Latin theatre existed: the faculty of arts at the University of Leuven, the Collegium trilingue or Busleyden College, and the Pegagogies that were connected to it. ${ }^{9}$ Their students were inspired to write and produce Latin plays when they became teachers or headmasters. On the Sunday of Kermis, September 3, 1508, students of Martinus Dorpius (1485-1525) performed one of the less scurrilous plays of the Roman writer of comedies Plautus, Aulularia (The Pot of Gold) with a prologue and a reconstruction of the lost fifth act of that play, under the title Tomus written by Dorpius himself. ${ }^{10}$ These performances fitted perfectly in Dorpius' teachings. At the Pedagogy 'The Lily' he had explained the play so thoroughly, that a performance was almost a natural result. He had read it in an attempt to reform his teaching, no longer dealing with grammar for its own sake, but explaining literary texts. Since most authors were edited in expensive folios, he took his refuge in extracts, which he could dictate or have copied, or to dramas that were attractive for their liveliness and practical utility as examples of everyday conversation.

The success of Dorpius' teachings and performances is proved by the many editions of the Aulularia from 1512 to $1540,{ }^{11}$ and by the activities of his friend and colleague Adrianus Barlandus (1486-1538), Latin teacher at the Collegium 'the Pork', who on Sunday February, 26, 1514, produced with his students the Aulularia, with Dorpius's addition and with a prologue by himself, and in September of the same year Euripides's Hecuba in the translation by Erasmus and with an introductory dialogue in Latin. Barlandus also produced Terence's Andria, Eunuchus, Adelphoe and Hecyra. For those performances too, he composed introductions or concluding dialogues. ${ }^{12}$ The example of Dorpius and Barlandus was followed at the Pedagogies with their many groups of pupils, who were the audience. ${ }^{13}$

The same Martin van Dorp wrote between 1506 and 1508 a Dialogus in prose, in which Virtus, Venus, Cupid and Hercules (in bivio) appeared. ${ }^{14}$ It has a very lively style and language and the characters of the personages show a pleasing diversion. The majestic Virtus, the cajoling Venus, the impetuous Cupid and the severe Hercules all talk in their own way. ${ }^{15}$ The dialogue breathes a fully classical atmosphere - it contains, for instance, many quotations from Valerius Maximus and a vernacular atmosphere as well, with some allegories that were so popular in Dutch literature. The dialogue was performed at the same pedagogy 'The Lily', in which he presented Hercules in bivio. In the prologue to it the humanist sets a high tone, speaking with disdain about 'jealous enviers' and uttering the wish to please only the small group of chosen connoisseurs,

\footnotetext{
${ }^{8}$ IJsewijn, 'Gli inizi del teatro umanistico nei Paesi Bassi Borgognoni'.

${ }_{9}$ The students of the artes were lodged and educated at four pedagogia or lodgings: the Lily, the Falcon, the Pig and the Castle.

${ }^{10}$ De Vocht, History, 1, pp. 215-16.

${ }^{11}$ See De Vocht, History, 1, p. 217 and n. 4.

12 See Daxhélet, Adrien Barlandus, pp. 209-20.

${ }^{13}$ De Vocht, History, 4, p. 106.

${ }_{14}$ Dialogus, in quo Venus \& Cupido omnes adhibent versutias, ut Herculem animi ancipitem in suam Militiam invita Virtute perpellant, see De Vocht, Monumenta Humanistica Lovaniensia, pp. 331-33; De Vocht, Jerome de Busleyden, pp. 253-54; see also Creizenach, Geschichte des neueren Dramas, 2, p. 53.

15 This was how Busleyden had described them in a letter of November 1513, see De Vocht, Jerome de Busleyden, pp. 446-47; De Vocht, History 1, p. 220.
} 
pauculis, quales est vos. Dorpius may have been inspired to write his Dialogus by the Declamatio of 1481. Another play in the same vein, Palamedes (1512) was written by Remaclus Arduenna from Florennes in the Belgian Ardennes, one of the leading humanist poets of his age (c. 1480-1524), who was educated at Liège and Cologne. In his allegorical play, mainly in prose, the choice of life is presented as a classical one: Palamedes hesitates to make a choice between Sophia ('Wisdom'), whom he loves, and Chrysos ('Gold') who seduces him. ${ }^{16}$ At first he makes the wrong choice for Chrysos, but finally he turns to Sophia who will help him to use the arbitrariness of Chrysos to his and others' benefit. It was, however, written and published in London; when the author moved to Paris, the play saw a second edition in that city, in the same year. These kinds of plays were composed in rivalry with ancient comedy, either to serve as a counterbalance to it, or because that repertoire soon would have been too small, and with an eye on allegorical drama in the vernacular.

In the environment of 'Leuven' the Latin schools in Flanders must have played an important role. What this role exactly was, we do not know, but the oldest reports on producing classical plays, from Plautus and Terence, and performances based on the Dido episode from Virgil's Aeneid, stem from these places, witness the Bruges performance. ${ }^{17}$ It is in this Leuven tradition that Erasmus wrote a dialogue in three acts between Thalia, the Muse of omedy and in this text a representative of humanist style, and Barbaries (Barbary) who represents medieval Latin: the Conflictus Thaliae et Barbariei, which was printed long after Erasmus' death. ${ }^{18}$ The dialogue that is situated at the famous Latin school of the Dutch town of Zwolle contains a 'Praefatio' in the vein of a Terentian prologue, and a short 'argumentum'.

Thus, one of the sources of Latin drama in the Low Countries was situated in Leuven, a centre of performances of ancient and newly written plays. The other origin, for writing and staging original Latin dramas, was situated in Germany, where the philosopher, Hebraist and playwright Johannes Reuchlin (or Capnio, 1455-1522) lived. He inspired the Brabantic teacher Georgius Macropedius. In a preface to the literary-minded youth, added to his first printed plays Aluta and Rebelles he states: 'I must confess that he [Reuchlin] was the first cause for me to write plays, he was the first to inspire me. ${ }^{19}$ He calls Reuchlin even 'this pride of our age and of Germany $(. .$. who was the first who restored the collapsed faculty of writing comedies' ${ }^{20}$ The Haarlem rector Petrus Nannius (1500-1557) in the dedicatory letter of his Vinctus (Bound, 1522) also acknowledges his debt to the German humanist who had written a Sergius, sive capitis caput (Sergius or Capo, written and staged in 1496, published in 1504) in which the commerce of relics is aimed at, and a Scaenica progymnasmata, better known as Henno (1498), a satire on astrologers and lawyers on the theme of the cheat hoist with his own petard. ${ }^{21}$

The length of the plays (Henno 449 lines, and Aluta 572 lines), the use of choral odes with musical notes, the name of the farmer ('Heino' in Aluta, cf. 'Henno') and other names, and verbal similarities all testify to the debt of Macropedius's Aluta to Reuchlin's plays. ${ }^{22}$ Macropedius was

\footnotetext{
${ }^{16}$ See CE s.v. Remaclus Arduenna [Godelieve Tournoy-Thoens] and IJsewijn, 'The Coming of Humanism’, p. 279.

${ }^{17}$ See also IJ sewijn, 'The Coming of Humanism', pp. 245-48.

18 A modern edition is made by René Hoven in ASD I, 8, pp. 357-67.

19 Macropedius, Rebelles and Aluta, 'Ad pueros bonarum litterarum studiosos': 'Is mihi primus (ut verum fatear) ansam scribendi dedit, is me primus excitavit.'

${ }^{20}$ Macropedius, Rebelles and Aluta, 'Ad pueros bonarum litterarum studiosos': 'hoc seculi nostri et Germaniae decus Ioannes Capnion (...) qui (...) conlapsum prosus artificium comicum primus instauravit.'

${ }^{21}$ Modern edition by Schnur. See also in this volume the chapter by Cora Dietl, pp. \#\#.

22 See also Macropedius, Aluta, ed. Bloemendal and Steenbeek, p. 26
} 
an autodidact: after attending the Latin school, he entered the Brothers of the Common Life, living in the atmosphere of the Devotio Moderna. To become a priest, the members had to study, but they were not required to attend university.

Here also the Munster teacher Johannes Kerckmeister should be mentioned. Munster in Westphalia may be counted as part of the Low Countries, because the area between Zwolle, Deventer and Munster formed one cohering cultural region. Kerckmeister staged and published a Codrus in 1485, a plea for a humanistic education in the form of a generational conflict between a scholastic professor and his progressive students. ${ }^{23}$

A third 'origin' is the classroom dialogue. Humanists wrote dialogues (colloquia) for their pupils to read and recite. Of course, the most famous ones that were widely used at the schools were those of Erasmus, the Colloquia familiari. But also the French reformer Mathurin Cordier or Mathurinus Corderius (1479-1559) wrote colloquies that were read in the Low Countries: Colloquia scholastica. The colloquies of Erasmus were also performed ${ }^{24}$ or a few times reworked into a drama. ${ }^{25}$ In Louvain Barlandus wrote Dialogi XLII, published in $1524 .{ }^{26}$ Other arguments for the dialogue being one of the forerunners of drama is that the word 'comedy' is used for dialogue and that some dialogues end with the formula 'valete et plaudite' so common in comedy. ${ }^{27}$

\section{The First Generation - Finding the Form in a Changing World (1500-1550)}

The first generation of Latin playwrights wrote mainly biblical dramas, either as a kind of critical reaction to Latin comedy, or as a logical consequence of it. Starting at the first decade of the sixteenth century, it more or less coincides with the first phase of the Reformation movements, which may determine the way they were and are read. The main centres for dramatic production in Latin were the Latin schools, the authors mainly headmasters. The choice of Terence and Plautus as main models has to do with this environment. The period ends with the publication of the Omnes fabulae by Georgius Macropedius in 1552/1553.

The very first modern Latin play by an author from the Low Countries was written abroad. In Italy the Dutch humanist Hermannus Knuyt van Slyterhoven (from Vianen near Utrecht) wrote a Scometta, published in Bologna, 1497. This play was named after a country house in the neighbourhood of Bologna, where Codrus, Lolla and Corydon have a love affair in a pastoral setting. ${ }^{28}$ This, however, is a 'Fremdkörper' in the history of Latin drama from the Low Countries.

\footnotetext{
${ }_{23}$ Modern edition by Mundt; IJsewijn, in Latomus, 30 (1971), 179-81, suggested some textual emendations. On Codrus, see the chapter by Cora Dietl in this volume.

${ }^{24}$ Holstein, Die Reformation, p. 38. In the School Ordinance of Hamburg, 1529 and in the School Ordinance of Schleswig-Holstein, both made by the reformer Johann Bugenhagen (1485-1558, it says: 'Item idt is ock eine gude övunge, wen man se Comedien spleen leth edder ettlicke Colloquia Erasmi' ('Further, it is a good exercise when one has comedies played or some Colloquies of Erasmus'). See also Roloff, 'Neulateinisches Drama', p. 650.

${ }^{25}$ Holstein, Die Reformation, p. 266. The anonymous who wrote the Lustspiel von der Weiber Reichstag (first performance Neurenberg 1537) took his subject from Erasmus' Colloquia.

${ }^{26}$ By the Louvain printer Dirk Martens. On Barlandus, see Daxhélet, Adrien Barlandus; CE 1, pp. 95-96 (C.G. van Leijenhorst); Meertens, Letterkundig leven in Zeeland, pp. 40-41.

${ }^{27}$ See, for instance, Comoedia vel potius dialogus de optimo studio scholasticorum, staged in Tübingen in 1501.

${ }^{28}$ Modern edition by Bolte. See IJsewijn, 'Theatrum Belgo-Latinum', pp. 81-82; Bahlman, Die lateinischen Dramen, pp. $23-24$.
} 
Within the Low Countries themselves, Neo-Latin drama started with the Bible. Whether intended to be polemical or not, the plays were often read in the light of the clash between Protestants and Catholics. The first original Neo-Latin play written and performed in the Low Countries had as its theme the Prodigal Son, from Luke 15, 11-32. Between 1506 and 1510 Brother Georgius Macropedius or Joris van Lanckvelt (1487-1558) by then working as a repetitor in 's-Hertogenbosch in the duchy of Brabant wrote Asotus evangelicus (The Prodigal Son of the Gospel. ${ }^{29}$ The play saw its first, revised edition only in 1535 . Besides paraphrasing a passage of Erasmus's Latin translation of Euripides' Iphigenia in Aulis (1506), Macropedius in his revision demonstrably used Erasmus's reworking of the Vulgate translation of the Bible (1516). ${ }^{30}$ Moreover, he quoted many of Erasmus's adages. These forms of reception show Macropedius's debt to evangelical humanism which was easily accommodated to Modern Devotion.

The opposition between the prodigal, younger son and the 'decent', older one could have been a way to take a stand in the quarrels of reformation on grace and the meritorious character of good works, but Macropedius presents it as an opposition in characters and in education. In the opening monologue Asotus's father Eumenius ('Well-disposed' or 'Gracious') complains about modern youth, embodied now in his youngest son. Influenced by wicked friends, among whom were some of Eumenius's own servants, Asotus goes astray. As a result of the moral and pedagogical aims Macropedius set himself as an author, he avoided the religious arena, although this turned out to be impossible: the theme of the Prodigal Son would soon figure in the controversy on grace and good works. Macropedius added a medieval and vernacular flavour to the play by interspersing it with scenes in which two devils (in the play called Astaroth and Belial) comparably to the 'sinnekens' in Rhetoricians' plays, comment on the action.

This play leads us to another general observation on humanist drama. While in ancient comedy of Plautus and Terence there was no chorus, some humanists re-introduced it. One may guess at the reasons. Macropedius would have been inspired to do so by Reuchlin, but another literary stimulus may have been the tragedies ascribed to Seneca that contain choral passages between the acts, even though they are not strophic like most humanist choral songs. Horace's Ars poetica may have given a theoretical impetus, with his remark that the chorus should play the part of an actor, and suggests that it enters between the acts. ${ }^{31} \mathrm{~A}$ more pragmatic reason may have been the possibility to give more pupils a role in a performance. ${ }^{32}$ The humanists themselves wondered why the chorus was lacking in Roman comedy. Laurimanus, in the prologue to his Esthera, thinks that this has to do with the replacement of the chorus by flutes. Therefore, there is no objection to re-introducing it. ${ }^{33}$ In the Omnes fabulae edition the choruses are printed with melodies,

\footnotetext{
${ }^{29}$ On the author Best, Macropedius and Giebels and Slits, Georgius Macropedius. Modern edition of Asotus by Puttiger. See also Bloemendal, Georgius Macropedius, offering an overview of his dramas with in-depth studies of aspects. A complete translation in Dutch of his dramas in Macropedius, Verzameld toneel. Circumstantial evidence on the date of Asotus can be found in the Apotheosis Macropedii: 'Nam vix dum coepit doctas tractare Camoaenas, / Quin iuveni nimium sors cito acerba foret' and 'a ter septenis annis, podagra quia saeva / Excruciaretur'. So around his $21^{\text {st }}$ year (in 1509) Macropedius started to write poetry. On Asotus, see Best, Macropedius, pp. 23-41; Giebels and Slits, Georgius Macropedius, pp. 225-33.

${ }^{30}$ Puttiger's introduction to his edition of Asotus, pp. 25-31, esp. pp. 27-28.

${ }^{31}$ Horace, Ars poetica 193-95: 'Actoris partis chorus officiumque virile / defendat, neu quid medios intercinat actus, / quod non proposito conducat et haereat apte' ('Let the chorus sustain the role of an actor and the function of a man, and let it not sing anything between the acts that does not purposefully and aptly serve and unite with the action').

32 It is telling that Macropedius, apparently troubled by the controversies of the Reformation, turned away from worldly topics as he grew older, while Schonaeus, living and working a generation later, could write farces and nonChristian plays throughout his career.

33 'Quid vetat igitur, cum tibiarum ratio nobis minime constet, ut chorum revocemus'.
} 
composed by Macropedius himself. This music fitted in the approach to music of the Modern Devotion $^{34}$ and in the fondness of the Dutch to sing.

Another play on the Prodigal must have been written and staged by the physician, historian and theologian Renerus Snoyus or Reynier Snoy (c. 1477-1537) in Gouda, before 1529. This play, however, was probably never printed, and we know nothing about it. ${ }^{35}$

The theme of the Prodigal Son also inspired the headmaster of the Latin school at The Hague, Guilielmus Gnapheus (or Willem Claesz. de Volder or Van de Voldersgraft, 1493-1567) who had studied in Cologne and probably at Louvain University. ${ }^{36}$ He wrote an Acolastus that was printed in 1529. It was the most famous play written in the Low Countries, which was often performed, printed, translated and adapted all over Europe. ${ }^{37}$ Gnapheus kept close to the story, but elaborated on vs 13: vivendo luxuriose with some tavern scenes in which he could imitate Roman comedy and its figures. The play may be summarised as follows: the Prodigal Acolastus ('Uncontrolled'), under the influence of his friend Philautus ('Self-love'), leaves his father Pelargus, falls in with two rogues, Pamphagus ('All-eating') and Pantolabus ('All-snatching'), is fleeced by the innkeeper Sannio and the whore Lais, dices away the rest of his money, and so is forced to work for the farmer Chremes. Meanwhile, Pelargus is persuaded by his confidant Eubulus ('Good-advice') to forgive his son unconditionally. Acolastus, near despair, suddenly becomes convinced that his father will accept him again. He returns home to receive a cheerful welcome. ${ }^{38}$ The play could be a Lutheran play, in which the theme of grace prevails, a play that reflects from a Lutheran standpoint the liberum and servum arbitrium controversy between Luther and Erasmus, or a play that is implicitly Protestant, making use of medieval commentary traditions, intertwining story and allegorical interpretation. ${ }^{39}$ While other playwrights confined typology and allegorical interpretations to the prologue or the epilogue, ${ }^{40}$ Gnapheus used them throughout the play. However, such an interpretation would be more readily recognized by readers than by an audience at a performance; the more so, since the theological treatment is very restrained, subtle and unaggressive. ${ }^{41}$ Gnapheus, unlike Macropedius, stuck to classical comedy and refrained from introducing choral songs.

In his letter of dedication Gnapheus shows that he was writing his play full of literary allusions for the republic of letters by stating that although the present age had produced masters in almost every literary genre, but no Menander or Terence. So the tone of this letter is not one of religious controversy, but of literary aspirations. 'To such an audience [i.e. a European learned audience], what was most conspicuous in Acolastus was not a Lutheran message but the deeply-held humanist conviction that the classical medium is an effective one for proclaiming the unchanging

\footnotetext{
${ }^{34}$ Grijp, 'Macropedius and Music'.

35 On Snoy, see Goudriaan, 'The Gouda Circle of Humanists', and CE.

36 On him, see recently Demoed's doctoral thesis 'Wie van gevaar houdt'.

${ }^{37}$ Ed. Bolte; ed. Minderaa; English translation Atkinson. See also Parente, Religious Drama and the Humanist Tradition, pp. 43; 44-45; 72-74; Bahlmann, Die lateinischen Dramen, pp. 39-42; Atkinson tried to assess its Lutheranism; Washof, Die Bibel auf der Bühne, pp. 204-06 also opts for a confessional choice for God's grace as the cause of salvation.

${ }^{38}$ Cf. Macardle, The Allegory of Acolastus, p. 1.

${ }^{39}$ For the first interpretation, see Wailes, 'Is Gnapheus' “Acolastus” a Lutheran Play?', the second one in Atkinson's introduction to his translation, pp. 51-67; for the third, see Macardle, The Allegory of Acolastus. One may also discern Erasmus in this play: In Luke 15, 17 the Prodigal asks himself, in the Vulgate translation: quanti mercenarii are in my father's house; Erasmus annotates: quanti should be quot or quam multi. Gnapheus, 1. 1161 phrases: quot mercennarii.

${ }^{40}$ Cf. Parente, Religious Drama and the Humanist Tradition, p. 72.

${ }^{41}$ See also Kearns, 'Pagan Wisdom, Christian Revelation', p. 212.
} 
Christian message. ${ }^{42}$ Although this may be true, it is also true that some plays were written in a polemical tone, or were read as such. In 1555 he published a reworked version of his comedy. ${ }^{43}$

Acolastus is a Christian play; it is also a fully Terentian one, in which both the old father Pelargus and the young prodigal son could be portrayed after Terentian, and their opposition is similar to that of the severe father Demea and the liberal uncle Micio in Terence's Adelphi or that of the father Menedemus and his old neighbour Chremes in his Heautontimorumenos. Also the unkempt life of the son had its Terentian forerunners in Eunuchus. Gnapheus succeeded in transferring the biblical theme into a classical comedy.

Gnapheus himself introduced humanistic school drama into Germany, when he fled there. He performed his Acolastus in Elbing, in 1536. Among the audience was the prelate and Latinist Johannes Dantiscus, and he showed his approval. Acolastus also shows another feature of Latin drama of the Low Countries: the choice of New Testament subjects, that had not been used in medieval drama.

The vicissitudes of Gnapheus' play, as well as the collection by Brylinger show the international scope of Low Countries Latin drama. Another early drama with a tremendous European resonance was the Euripus (1549) by the Antwerp Friar Minorite Levinus Brechtus (1515-1560). ${ }^{44}$ Initially written for the students of the Leuven College 'The Falcon', and performed on 1 July, 1548, this tragoedia christiana was staged at Jesuit Colleges from Toledo to Vienna, from Cambrai to Munich. In Prague it was presented in German before ten thousand spectators in February 1560. Thus, Euripus became one of the cornerstones of Jesuit drama in Europe, but it also united Protestants and Catholics: Lutherans attended a performance of the play by the Jesuit College in Augsburg. ${ }^{45}$

The theme of Euripus is a variation of the Everyman theme: the young man Euripus ('Wavering') ${ }^{46}$ personifies the young man who is easily led astray. The play starts with a dialogue between Venus and Cupid, dressed as devils. Euripus has escaped them and put his faith in Fear of God, who 'dressed as a doctor or a philosopher' accompanies him on his long and difficult journey. Venus and Cupid, now in a beautiful appearance, seduce him. However, he shuns admiration of the vices that Venus hides under her garment, such as adultery, murder and debauchery, and flees with 'Time of Grace', a young man dressed like an angel. But then the road is too hard, and he returns to the two pagan deities of love and lust. They cheer when Death and Plague visit Euripus and torture his soul after death by depicting all the punishments of hell. Brechtus introduced two choruses in his play: a chorus lamentantium (of lamenting people) and a chorus daemonum aëriorum (of heavenly spirits).

One of the themes in the play is the broad way and the narrow path (Matthew 7, 13-14); whether these were actually shown on the stage, or depicted in words. Euripus treads the latter, difficult path with Timor Dei ('Fear of God') and Tempus gratiae ('Time of grace'). However,

\footnotetext{
${ }^{42}$ Kearns, 'Pagan Wisdom, Christian Revelation', p. 213.

43 Printed in Antwerp by J. Loeus. See also Demoed, 'Wie van gevaar houdt'.

${ }^{44}$ See Valentin, 'Aux origines du théâtre Néo-latin’; idem, Les jésuites et le théâtre, pp. 202-04; Wimmer, Jesuitentheater, Rädle, 'Aus der Frühzeit des Jesuitentheaters', and the contribution by Rädle in this volume, pp. \#-\#.

${ }^{45}$ Wimmer, Jesuitentheater, p. 119.

${ }^{46}$ See Erasmus, Adagia 862 (I.9.62): 'Euripus homo in inconstantes ac moribus inaequales homines dicetur .... Ducta metaphora a maris Euripi prodigiosa quadam reciprocandi celeritate' ('Man's a Euripus, is to be used of those who are changeable and of no settled character ... The image is taken from the prodigious speed with which the Euripus ebbs and flows', CWE, 32, pp. 215-16).
} 
already after a few yards he wants to rest, even though Timor Dei warns him for the proximity of Venus and Cupid. When Euripus sleeps, Venus enchants him with a 'suavis symphonia'.

The play is full of allegories, thus mirroring the contemporary morality of the Rhetoricians. ${ }^{47}$ Their most famous play was the Dutch Elckerlijc (c. 1496), rendered into English in the form of the 'morall playe' Everyman. ${ }^{48}$ The play portrays 'Every man's' hour between the appearance of death and the actual moment of dying, representing it as a pilgrimage. It is typical of the city, because its protagonist is a rich citizen who has forgotten how he can be saved in spite of his wealth, i.e. by sharing his possessions with the poor, and it was written in the urban context of the Rhetorician's Chambers. The play already had been remade in Latin, by the Maastricht priest and schoolmaster Christianus Ischyrius (or Stercken, d. after 1536) ${ }^{49}$ as Homulus (1536) and by Macropedius as Hecastus (1539). All these plays have as their central question: 'what is a person's consolation in the hour of death?' or 'what gives the sinful human being entrance to eternal life instead of damnation? ${ }^{50}$ Homulus ('Invalid creature') is fully embedded in Catholicism: Homulus, abandoned by all, addresses himself directly to Mary, confesses his sins to a priest, sings the praises of the Church's seven sacraments and is saved by them, and refers to the doctrine of transubstantiation. ${ }^{51}$ Ischyrius reworked the 'sinnespel' into a classical five-act comedy, increasing it with humanistic education by using classical metres and the learning of Antiquity. It contains thoughts and phrases derived from classical authors, mainly Plautus and Terence, but also Horace, Ovid and Seneca. It also echoes passages from the Bible and the Christian Fathers of the Church. Furthermore, the author added a prologue and an epilogue in which the moralisation is made explicit. However, following ancient comedy, he did not introduce a chorus. In the play itself he often stays close to the original Dutch text. Ischyrius was aware of the tension between classical lore and Christian religion: 'Here you have, dear reader, a comedy that is both pleasant and pious. Yet, although it does not have the charm of Terence or the eloquence of Plautus, yet it depicts the life of a Christian and the frailty of this world's wealth and weighs them as on a balance. ${ }^{52}$ In its turn the play was translated into German by Jaspar von Gennip, who also had printed the first edition of the Latin play.

\footnotetext{
${ }^{47}$ Meyer, 'Zur Präsentation und Deutung von Sinnbildern auf der Jesuitenbühne', esp. pp. 396-98.

${ }^{48}$ Its full title runs: Den Spyeghel der salicheyt van Elckerlijc. Hoe dat elckerlijc mensche wert ghedaecht Gode rekeninghe te doen (The Mirror of Salvation of Everyman. How every man is summoned to account for his actions to God). First edition Delft Christiaen Snellaert, 1496; $2^{\text {nd }}$ edition Antwerp, Govaert Bac, 1501. The edition by the Antwerp printer Willem Vorsterman ca 1525 is a poor print, but the first complete edition that survived. Modern editions in Ramakers and Wilmink, Mariken van Nieumeghen en Elckerlijc, pp. 151-223; Davidson, Walsh and Broos, Everyman and Its Dutch Original, Elckerlijc.

${ }^{49}$ On Ischyrius, see NNBW, 8, coll. 905-06 (J.F.M. Sterck); on the Everyman theme in Latin and vernacular plays see, for example, Wiemken, Vom Sterben des reichen Mannes; Goedeke, Every-man, Homulus und Hekastus; Bolte, Drei Schauspiele vom sterbenden Menschen; Bloemendal, 'Transfer and Integration'.

${ }^{50}$ A similar theme can be found in Thomas Naogeorgius's Mercator (1539) and Jacob Bidermann's Cenodoxus (1602), see the chapter on German humanist drama by Cora Dietl, pp. \# and \# resp.

51 The full title is Homulus Petri Diesthemii, Comoedia in primis lepida et pia, in rem Christiani hominis adprime faciens, Antverpiae quondam in publico civitatum Brabanticarum conventu vulgariter acta, palmamque adepta ('The Everyman of Peter van Diest. A comedy that is above all pleasant and pious, contributing foremost to a Christian's interest, once played in public in Antwerp at a meeting of the Brabantic cities and where it won the first prize'). Modern edition by Roersch. 52 Ischyrius, Homulus, preface 'To the pious reader and the upright youth': 'Habes, candide lector, comoediam non minus lepidam quam piam, quae tametsi Terentij venustatem aut Plautinam redoleat eloquentiam, tamen Christiani hominis vitam, mundique huius luxus fugacitatem, tanquam ex quodam perpendiculo depingit \& aestimat.'
} 
The same classical learning was added by Macropedius to his famous Hecastus (Everyman), which, however, was less 'Catholic'. ${ }^{53}$ While in Elckerlijc and Homulus the priests summon their audience to good deeds and the Christian life, stressing that a sinner can be redeemed by remorse, repentance and reform, in Hecastus (published in Antwerp by Michael Hillen, 1539) things are less straightforward. Hecastus is strengthened by the sacraments, but faith in God's grace and Christ's redeeming death are presented as necessary (1065-66) for salvation. Mary is barely mentioned; there is no penitence, nor any giving of alms. The chorus he employs consists of three boys and three girls of the family ('Chorus ex tribus pueris et tribus puellis familiae'), at which it is to note that likely the girls' roles were sung by boys, too.

This less strict adherence to Catholic doctrine was related to Macropedius's own education at the school of the Brethren of the Common Life in 's-Hertogenbosch, who practised the devotio moderna of Geert Grote. Macropedius himself became a member of the Brethren, who aimed for a practical religion, faith expressing itself in good deeds, piety practised in copying sacred books and illuminating them, but also in the education of children and reading the Bible every day. They had an aversion to dogmatism. In this atmosphere, Macropedius was little concerned with the orthodox, Catholic mainstream.

Although Macropedius was not that interested in Catholic doctrine, he reworked the play in 1552 and 1553 for the publication of his Omnes fabulae. While, in the first version, he had the protagonist Hecastus find consolation mostly in faith, in his belief in Jesus Christ, in the second the author inserted some lines and scenes which showed that he adhered to the Church and its tenets and sacraments as the foundation of salvation and consolation.

This was connected with the repressive measures the authorities took after the Rhetoricians' feast in Ghent in $1539 .{ }^{54}$ There, the question to be answered in dramatic form was 'what is man's consolation at the hour of his death?' - the same question as addressed in Elckerlijc and its imitations. Some of the plays that were performed there - and later printed - gave Reformationist answers to the question: 'Christ', or 'faith', instead of 'the sacraments', 'the church', etc. Moreover, the Ecumenical Council of Trent (1545-1563) clearly specified Catholic doctrines on salvation and the sacraments, in reaction to the Protestant Reformation movements. Macropedius got involved in matters of orthodoxy and heterodoxy, whether he wanted to or not.

There were many more biblical and other religious dramas written in this first phase in the Low Countries. Leuven, with its University, the Collegium trilingue and the Pedagogies, often was the source of inspiration. The Amsterdam schoolmaster Cornelius Crocus (Cornelis Croock, ca 1500-1550) studied in Louvain with Alardus of Amsterdam and Barlandus from 1517 on. As a Catholic priest and a rector of an Amsterdam school, in 1536 he published a very successful biblical comedy (comoedia sacra) called Ioseph, that had been performed publicly in $1535 .{ }^{55}$ It was printed at least seventeen times between 1536 and 1549, in the Low Countries, in France and Germany and it was adopted into the compilation of comedies by Brylinger (1540) and Oporinus

\footnotetext{
53 See Best, Macropedius, on Hecastus, pp. 11-24; Giebels and Slits, Georgius Macropedius, on Hecastus, pp. 252-66. Modern editions of the play in Dammer and Jeßing, Der Jedermann im 16. Jahrhundert.

${ }^{54}$ Van Bruaene, 'Printing Plays'; Leys, 'L'"Hecastus" de Macropedius et le “Landjuweel” de Gand (1539)'.

${ }^{55}$ Full title: Comoedia sacra, cui titulus Ioseph, ad Christianae inventutis institutionem iuxta locos inventionis, veteremque artem nunc primum et scripta et edita per Cornelium Crocum Aemsterodami ludimagistrum. Ex Genesios cap. 39. 40. et 41 (Antwerp: Johannes Steelsius, 1536). See on this play Lebeau, Salvator mundi, pp. ; Wimmer, Jesuitentheater, pp. 45-60; Spies, 'A Chaste Joseph for Schoolboys'; edition by Bloemendal. On Crocus himself, see CE s.v. Croock (C.G. van Leijenhorst) and $A D B$ (Johannes Bolte).
} 
(1547). ${ }^{56}$ Most likely, he was inspired by his teachers in Louvain and by the success of some other playwrights, among them Macropedius and Gnapheus. In his Ioseph he dealt with the story of the seduction of Joseph by the wife of Potiphar, his imprisonment and release from prison (Genesis 39-41), thus focusing on the seduction. Both quotations from Erasmus's works, including one that was used as a motto for the play, and the use of pagan literature to advance Christian truth and living well, wisdom being a sancta eruditio that initially comes from Christ, designate Crocus as an Erasmian author, who combines a Stoic and a Christian outlook in his resignation of wealth and bodily pleasures and his admonishment of his pupils to pursue wisdom.

It is this combination of pagan wisdom and Christian revelation, that is a major theme for Crocus. ${ }^{57}$ In the letter of dedication, he also ascribes a forceful influence of a classically embellished style on the pupil's minds, quoting the famous passage from Lucretius that poetic form makes the content more agreeable as the honey with which doctors sweetened bitter medicines. ${ }^{58}$ Theologically, he presented Joseph's rejection of Potiphar's wife and his imprisonment to create a crisis so that God's liberation of him from prison would illustrate His righteousness. Typologically, this plot shows in God's release of Joseph from prison Christ's redemption of man. Crocus remained an Erasmian, also after his religious development and entrance to the Jesuit order in the '40s. In 1548 an edition appeared with some additions. A dedication to the orthodox Amsterdam burgomaster Hendrick Dircksz was added, as well as a part of a poem by Paulinus of Nola: 'Brevis exegesis historiae' ('A Short Explanation of History'). Another change aimed to be of aid for the non-Latin audience: a 'Cantio vigilis' (a 'guardian song') in Dutch, to be sung between the fourth and the fifth acts. The introduction to this song reveals that a trumpet sounded in the fifth act, one of the scarce indications of performance practices.

After the '40s, Crocus revised the play considerably, mainly for stylistic reasons. This edition, according to the title page recognita utraque et aucta per Cor. Crocum ('both revised and augmented by Cornelius Crocus') was published by the same Antwerp printer Steelsius. It turned out to be a failure, either for ideological reasons, or - more likely - because of saturation of the market for biblical dramas by the 1550s.

In its first version, Crocus' play had a tremendous resonance in the German speaking countries where it was translated and imitated by Hans von Rüte (d. 1558) in Bern, by Sixt Birck or Sextus Beteuleius (1501-1554) in Augsburg, by Jakob Rueff or Ruf (1500?-1558) in Zurich, all in German, and in Latin by Andreas Diether (d. 1561), for his students in Augsburg. ${ }^{59}$ In 1583 Jonas Bitner or Büttner (1520?-1590) again translated the play into German, while the Polish poet Simon Simonides or Szymon Szymonowic (1558-1629) was inspired by it for his play Castus Ioseph (The Chaste Joseph, 1587) ${ }^{60}$ and these would not be the last plays based on Crocus' Ioseph.

In the Low Countries themselves Crocus's Ioseph inspired Macropedius to compose his own Iosephus (1544). In his lengthy play (over 2000 verses in 41 scenes). Macropedius adopted more elements of the story in his play, such as the explanation of the pharaoh's dreams, the appointment of Josef as viceroy and his marriage with the Egyptian princess Asnath, who in his

\footnotetext{
${ }^{56}$ Comedia [sic] ac Tragoediae aliquot ex nouo et vetere Testamento desumptae (Basle: Nicolaus Brylinger, 1540) and Dramata sacra: Comoediae atque tragoediae aliquot e Vetere Testamento desumptae (Basle, Johannes Oporinus, 1547).

${ }^{57}$ Kearns, 'Pagan Wisdom, Christian Revelation', pp. 231-38.

${ }^{58}$ Lucretius, De rerum natura 1, 936-38; cf. Quintilian, Institutio oratoria 3, 1, 4. Crocus also mentions the objections to theatre raised by St. Jerome and Lactantius.

${ }^{59}$ See the contribution by Cora Dietl.

${ }^{60}$ See the contribution on Eastern European drama.
} 
version is the daughter of Josef's former master and mistress, in the play called Aegla ('Radiance') ${ }^{61}$ Rather than observing the unity of time, he wished to adhere to the biblical story, as he tells us. Macropedius's canniness finds its expression in the prologue, which closes with the request that the audience should not be offended by Aegla's shameless words or actions, for without them, Joseph's chastity cannot be shown. In contrast to the prudish Crocus, who keeps the attempt at seduction off-stage, Macropedius gives full exposure to the lust of his villainess. ${ }^{62}$ Showing the entire story, he could give his play a neat, comic ending. He also is more explicit about the behaviour of Potiphar's wife than Crocus was and does not shun to show the scène-àfaire. Just like Crocus, Macropedius shows Aegla's lack of balance in her misbehaviour towards her servants. In Act 2, scene 1, Joseph compares his situation to that of Hippolytus in relation to Phaedra.

The rector scholae also gave the play a Christian-instructional turn, by having Asnath teach the Crede and the doctrine of Holy Trinity. It is obvious: Catholic Christianity already won the plea in Potiphar's family. Asnath is given a prominent place at the end of the play, when she marries Joseph. Her father and mother, Potiphar and Aegle, repent and acknowledge in a kind of anagnorisis that they deserve to be punished. ${ }^{63}$ Another feature of the play is that both had 'raised Joseph as their own son'. Thus the story gets some resemblance with the Greco-Roman story of Phaedra who fell in love with her stepson Hippolytus. ${ }^{64}$ Next to this, the figure of Joseph as

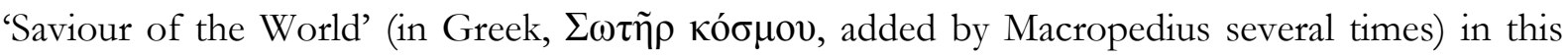
play, as in Christian tradition of exegesis of the Old Testament, is a prefiguration of Christ, and Aegla and Asenath allegorically represent Judaism and Christianity.

This Iosephus was performed in Antwerp in 1564 in a translation by Antoine Tiron. ${ }^{65}$ Unlike Crocus, Macropedius in this play also added a chorus, sung by 'the family present' ('chorus per familiam praesentem'), by Joseph and prisoners ('per Iosephum et Captivos'), or based on a biblical passage ('ex Esdrae libro tertio').

One of the early biblical plays is also the Susanna (1532) by the Dominican monk Johannes Placentius (or Struyven, c. 1500-c. 1548) from St. Truyen who was educated by the Brethren of the Common Life in 's-Hertogenbosch. He was the first to dramatize this story from the apocryphal part of Daniel in Latin. ${ }^{66}$ The action is presented in some 500 verses, in which the surprise scene in the garden, when the two elders gaze at the chaste Susanna, with agitating flattering and threatening words, is presented in witty stichomythia. Perhaps this Placentius is the same as Eusebius Candidus, whose name is on the title of a play entitled Plausus Mortis (1532), a

\footnotetext{
${ }^{61}$ On the play, see Best, Macropedius, pp. 137-53; Giebels and Slits, Georgius Macropedius, pp.. 240-51. In Genesis 41, 45 Pharaoh gives Aseneth to Joseph; she is the daughter of Potiphar, a priest in Heliopolis who happens to bear the same name as Joseph's master. Macropedius identifies both persons.

${ }^{62}$ See also Best, Macropedius, pp. 137-38.

${ }^{63}$ Perhaps an allusion to the sacrament of confession with repentance and punishment, implicitly directed against Luther with his sola gratia.

${ }^{64}$ See also Lebeau, Salvator mundi, p. 89; 140-41 and 641. Vondel's Joseph in Egypten (Joseph in Egypt, 1640) also remains close to Seneca's Phaedra.

${ }^{65}$ See Lebeau, Salvator mundi, p. 84.

${ }^{66}$ Daniel 13. See on the play Brown, 'The Susanna of Johannes Placentius'. Its full title runs: Susanna Per Placentium Evangelisten lusa (Antwerp, Martin de Keyser, 1532). NK lists three other editions: (Antwerp: Martin de Keyser, 1534), (Antwerp: Michael Hillen van Hoochtstraten, 1534), and (Antwerp: Willem Vorstermsn, 1536), nrs 3734, 3735, 1728 and 3736, resp. On Placentius, see also the (unpublished) thesis by Stijn Buiter. In the vernacular plays were written on the Susanna theme, too, see Worp, Geschiedenis, 1, p. 21.
} 
death-dance play in which ecclesiastical and social wrongs are exposed. ${ }^{67}$ The play is very compact, running to some 530 lines, yet having a five-act structure, but no chorus. In the 'Epigramma' preceding Susanna, Placentius stresses that 'biblical stories' ('divinas historias') are more appropriate for the young to present 'than the frivolous ones of the ancients' ('veterum quam [...] leves'). Both in the title and the 'Epigramma', Placentius refrains from any designation of the play as comedy or tragedy. In the 'Argumentum', in line with ancient comedy, he gives an outline of the story, in which Susanna is opposed by 'the highly impious old men' ('senes impiissimi'), unnamed in the Bible, but here called Crito and Chrisalus, 'full of rage, lust, greed, gluttony, in short of all vices' ('ira, libidine, avaritia, gula, omnibus / Breviter malis foeti'). As Brown observes, 'Placentius, as a Catholic author, might well be making a statement on the autonomy and power of the will; certainly Susanna is kept from sin through the power of her personal rejection of evil, and Chrisalus [...] would not be deserving of the death sentence unless his own actions condemn him. ${ }^{, 68}$ Besides these, also other characters known from the Bible appear, like Joachim, Helchias, and Daniel. At the end, poetic justice is done: the evildoers are punished - in the final scene the carnifices announce that the elders will be executed offstage - and the virtuous rewarded. Further Placentius adapts stock characters from the classical models, but he exploits them in the first half of his play for comic purposes. All in all, in Susanna the moral didacticism is implicitly demonstrated in the proper conduct of Susanna.

A year after Susanna was published, the Breda author Jacobus Zovitius from Zeeland (1512-?) wrote a play on the Old Testament story of Ruth (1533). ${ }^{69}$ Zovitius, too, had attended the Leuven Collegium trilingue, where he may well have been inspired to use Latin plays as didactic material. In 1533, he was an assistant schoolmaster ('hypodidascalus') at Hoogstraten and aged just twentyone, as he states in the dedicatory letter to his Ovis perdita (1539), in which he defends the play that had not been well received. The story of the faithful Ruth the Moabite is appealing; the author is innovative in his treatment of some episodes, for example, in the introduction of two vagabonds and in the impressive scene where Ruth decides to follow Naomi (Noemi in the play, Ruth 1, 7-17; Zovitius, Ruth II.4). Zovitius depicts the heroine as a pagan philosopher already determined as a result of her rational convictions, ${ }^{70}$ who can rebuke her sister Orpha for not making the same decision. ${ }^{71}$ In church history the story of Ruth was loaded with many interpretations, for instance, in the adoption of a gentile in the Jewish people as an anagogical prefiguration of the ecclesia de gentibus, and in her appearance in the ancestry of David, as a foremother of Christ. Zovitius ignores these overtones, and gives the story a philosophical-ethical

\footnotetext{
${ }^{67}$ Three of Eusebius Candidus' poems are published together with Susanna; Placentius had written another poem of his, Pugna Porcorum, under a pseudonym and the letters of dedication reveal that Eusebius Candidus and Placentius move in the same circles, see Vanderheyden, 'Een dodendansspel', pp. 58, 62 and 86.

${ }^{68}$ Brown, 'The Susanna of Placentius', pp. 247-48. See also Pilger, 'Die Dramatisierungen der Susanna im 16. Jht.'.

${ }^{69}$ On Zovitius, see the introduction to the edition of Didascalus by Vloeimans, pp. 7-9, and Vosters, 'Jacob Zovitius'; on Ruth, Kearns, 'Pagan Wisdom, Christian Revelation', pp. 217-31 and Zovitius, Didascalus, ed. Vloeimans, pp. 1011. Ruth was published by the Antwerp printer Michael Hillen (NK, 4106).

${ }^{70}$ For example, she does so in her reaction to Noemi complaining about her loss of property and nobility. Ruth tells her that true nobility depends on virtue and true property cannot be taken away, 11. 145-54 and 151-71. Orpha ironically interrupts: 'Haec / Aut ex Stoa aut Academia Platonica / Prodit, quae ita in numerato habet Philsophiae / Dogmata.' ('She is springing from the Stoa or the Platonic Academy, since she has the tenets of philosophy ready at hand'). In the decision scene II, 4, Ruth stresses the Stoic doctrine of 'home everywhere': 'Mater, solum omne patria / Est forti, ut aequor piscibus' ('Mother, for a virtuous person the whole earth is his fatherland, like the sea for fish'), cf. Ovidius, Fasti 1, 493.

${ }^{71}$ Kearns, 'Pagan Wisdom, Christian Revelation', p. 219.
} 
interpretation of Stoic calm towards misfortune and pagan wisdom being an ancilla to reach the Promised Land, i.e. Christian faith.

Six years later, in the same year that Macropedius's Hecastus saw the light of day, Zovitius's second play, Ovis perdita (1539) was published, representing the parable of the lost sheep (Matthew 18, 12-14; Luke 15, 4-7). ${ }^{72}$ Zovitius now was teaching in the Brabantic city of Breda. This play was rather successfull; it was reprinted in 1540 and 1541 and, like Ruth, included in the compilation by Brylinger in 1540. In the play Jesus Christ appears (called both Soter and Salvator, 'Saviour') together with his servant Helias (Eliah). Further all kinds of allegories make their appearance, such as Justice, Jealousy, World and Flesh. Through this allegorical form the play is rooted in medieval and especially Rhetoricians' drama. The printed play has a special feature in the marginal notes indicating the quotations of biblical passages or allusions to them, from the Old and the New Testament, and from the apocrypha. The Latin periocha preceding the play has the form of an acrostich, the first letters forming the title 'OVISPERDITA', as can be seen in more periochae in Low Countries of the time, in imitation of argumenta to plays by Terence. The play ends with a festive supper to celebrate the salvation of the lost sheep. It was found and saved thanks to the character of Eleemosyna (or Misericordia). Perhaps this was Zovitius's reaction to the measures authorities took against heretics in the famous year $1539 .{ }^{73}$ Ovis perdita was not only reprinted, but also reworked by the German priest and teacher Jakob Schöpper under the same title (1553). ${ }^{74}$ Schöpper, however, replaced the part of Jesus by a shepherd. Zovitius's play was also known in Spain, where in 1558 an imitation appeared, Oveja perdida, in Spanish.

The schoolmaster Petrus Papaeus from Menen (in Flanders) staged another parable from the New Testament in his Samarites (1539), dealing with the Good Samaritan (Luke 10, 29-37). ${ }^{75}$ Papaeus or Papeus adapted the biblical story by depicting the 'man who fell among thieves' as the Prodigal; the first three acts of the play are devoted to his vicious life, thus applying the principle of 'contaminatio' to a biblical story, and introducing Terentian thieves, parasites and lovers. The young man, called Aegio, leaves his father-by-adoption Megadorus; the devil Leno ('Brothelkeeper') seduces him with the help of the parasite Gula ('Gluttony') and the slave Hedylogus ('Sweet-speaker') to love the girl Sarcophilia ('Loving-of-Flesh'), living in Jericho. This meretrix, they tell him, is already 'deadly in love' with him. Similar to the first scene of Plautus's Pseudolus, a love letter of Sarcophilia is read to him. On his journey he is robbed by the thieves Cupido, Bacchus and Death, and then helped by the Samaritan. The play, without a chorus, is fully allegorical, also in the main story: Aegio represents mankind, his master Eubulus ('Good Advise') reason, Megadorus God, and the oil the Samaritan uses for Aegio represents Holy Spirit's grace. The parasite play is modelled upon Plautus's comedies, and the story is interpreted in the sense of the old religion: the Samaritan was equated with Christ and with the Church. 'The Samaritan's entrustment of Aegio to the care of the innkeeper was thus interpreted by Papeus as Christ's

\footnotetext{
${ }^{72}$ See on the play Zovitius, Didascalus, ed. Vloeimans, pp. 11-12.

${ }^{73}$ See above, p. \#.

${ }^{74}$ See on him the contribution by Dietl, p. \#\#.

75 On the play, see, for instance, Abbé, Drama in Renaissance Germany and Switzerland, p. 134, Worp, Geschiedenis, 1, p. 215; Washof, Die Bibel auf der Bühne, pp. 156-62, who sees the warning for lust as its main theme. On Papaeus, see $A D B$ s.v. Papeus (Hugo Holstein). Its full title: Samarites comoedia de Samaritano evangelico (Antwerp: G. Montanus, 1539). It was also adopted in the collection of Comoediae ac tragoediae ex Novo et Vetere Testamento (Basle: Brylinger, 1540).
} 
transmission of his church to the rule of St. Peter and his successors. ${ }^{76}$ Thus, Samarites was meant to be a Catholic response to Gnapheus's Acolastus mirroring the act of salvation, and justifying and glorifying the power of the Church. The play was printed in five editions in the Low Countries and in Germany, and even a Spanish one, with scholia by Petrus Vanegas. ${ }^{77}$

Mystic and allegorical interpretations were also foregrounded by Johannes Sylvius (Jean du Bois, last half of the sixteenth century), a physician from Lille, in his Isaacus Xylophorus (1548, printed 1554) on Isaac's sacrifice. ${ }^{78}$

When we talk about biblical drama, we discern plays by subject, but we could also discern the religious nature by means of presentation. Some dramas presented their Christian message by allegory only, others by 'real' characters. It has to be noted, however, that the connections are thin between, for instance, a father in Acolastus representing himself and every father and God as a true-to-life character and 'fully' allegorical characters.

Allegorical by nature are Gnapheus's Morosophus (1541) and Hypocrisis (1544). ${ }^{79}$ Both plays were published during his period of exile in the German countries. In Morosophus two plots are to be discerned, one of which resembles that of Rhinoceros (1959) by the Romanian-French playwright Eugène Ionesco (1909-1994), and the plot around the protagonist Morosophus ('The Foolish Sage'). The musician Morus ('Fool') wants to become an astronomer or astrologist and henceforward to be called Morosophus. He predicts a special rain that will madden everybody who is touched by it. He encloses himself in his house in order to remain wise, so that he might become a wise king among the fools. The effect is the opposite: everybody ridicules him, especially two farmers. The second plot circles around Morosophus's antagonist Sophia ('Wisdom') and her companions Fides, Spes and Caritas (the theological virtues of 1 Cor 13, 13) and Theophilus ('Who loves God' and 'Who is loved by God'); he is sent out to spread the gospel. In the final act Theophilus meets the fools, of whom only Morosophus joins Sophia. The plot is based on a passage form Paul's first letter to the Corinthians $(3,18)$ : 'If any man among you seemeth to be wise in this world, let him become a fool, that he may be wise' (KJV), which was added as a motto to the printed version of the play. There has been discussion about whether the criticism in Morosophus is directed against the astronomer Nicolaus Copernicus (1473-1543) because of Morus's wish to become an astronomer, or against religion, especially against some forms of Lutheranism. ${ }^{80}$ As a matter of fact, Theophilus was an alias of Martin Luther, so if the Copernicus interpretation is right, the religious one cannot be ruled out; both interpretations may exist.

In Hypocrisis (1544) the Catholic Church is fiercely attacked. ${ }^{81}$ The protagonist Psyche has abandoned her serious studies to live a luxurious life, of which her marriage with Cupid is a symbol. She is accused by Apollo, the Muses and the Graces of disgracing literature and the humanist educational ideal. Thus, the play implicitly warns the students not to abandon their

\footnotetext{
76 Parente, Religious Drama and the Humanist Tradition, p. 73.

77 Toledo, 1542. See Creizenach, Geschichte des neueren Dramas, p. 71.

${ }^{78}$ Isaacus Xylophorus, comoedia, Jo. Sylvio Insulensi authore (Ypris, Jodocus Destresius, 1554). On Sylvius see Foppens, Bibliotheca Belgica, 728.

${ }^{79}$ See Demoed's doctoral thesis on Gnapheus, 'Wie van gevaar houdt', ch. 7. On Morosophus see also also her 'Stultitia on Stage' and Rädle, 'Zum dramatischen Schaffen des Guilielmus Gnapheus im Preussischen Exil'. A new edition of Morosophus was made by Hoffmann.

${ }^{80}$ The latter standpoint is defended by Rädle, 'Zum dramatischen Schaffen des Gulielmus Gnapheus im preussischen Exil', the first - unconvincingly - by Hoffmann in the introduction to his edition, pp. 20-24.

81 On this play, see Demoed, 'Wie van gevaar houdt, moet dat met de dood bekopen', ch. 9 and 4; ead., 'Theatre in Court' and 'The Morality of Hypocrisy', esp. p. 111.
} 
studies. She is assisted by her lawyer Hypocrisis, a personification of hypocrisy and justification by good deeds. The discussion at the trial between Apollo and Hypocrisis becomes a struggle between evangelical humanism and Catholicism. At the end of the play the character of Calliopius as an Epilogus admonishes the audience to look at the tableau vivant ('viva pictura') that will appear, showing Psyche at the feet of God, with Graces and Muses around her. In this way, Gnapheus introduced a feature of Rhetoricians' drama into a Latin play. With all this, Hypocrisis is a polemical drama, that Gnapheus could produce in Königsbergen, in the Lutheran eastern part of Prussia.

Writing and staging polemical plays was not quite harmless. In 1547 Gnapheus was accused of heresy, i.e. deviation from Lutheran doctrine. The prosecutors used the plays Morosophus and Hypocrisis as evidence. It is, however, not clear whether unorthodox remarks in the plays are the reason for the accusation, or just a means of hitting Gnapheus, who had made himself unpopular among his colleagues by accusing them of neglect of their duties. He also engaged in religious debate in other ways than drama: he wrote pamphlets in Dutch and in Latin.

The Eusebia sive Religio of Antonius Schorus (d. 1552) from Hoogstraten, who visited the Gymnasium of Johannes Sturm in Strassburg and later became a teacher at the University of Heidelberg, was performed by his students in Heidelberg on Epiphany of $1550 .^{82}$ The play of Religion criticizes the rulers of this world; therefore, Charles V decried it to the Archduke of the Pfalz, and Schorus had to flee. It may be for this reason that the play could not be printed. The action had indeed been clear enough. Religion appears on the stage, clothed in rags and seeking rescue from representatives of the several classes: a bishop, a prince, a physician, a jurist, a theologian. None of them wants to help her, since they are all afraid to abandon their easy life for an uncertain one.

In this way, the dramas of the first period not only mirrored the religious schism of the time, but also formed and deepened it, and instilled the schoolboys' minds with the wished-for doctrine: for instance of grace and mercy in the case of Gnapheus, and of grace and the Church in the case of Papaeus. Whether meant to do so (as often was the case) or not, the spectators and readers were ready to interpret the plays in this manner. Thus educational drama with moral instruction was combined with polemical theatre and religious topics. Either the antagonism of Protestant and Catholic faiths was incorporated in the plays' theme, or pagan knowledge was used to deepen Christian belief.

Many of the authors felt forced to defend themselves for writing comedies in general, and biblical comedies in particular. Macropedius, for instance, puts the rhetorical question: 'What would be more useful for the youngest pupils to obtain knowledge, for the elder ones to study literature, for the advanced students, or even for all to reach virtue, than a learned comedy? ${ }^{83}$ Brechtus has the Prologus bid the public to be silent and do nothing: 'that could prevent the spiritual fruit of the play, ${ }^{84}$ thus stressing the fructus. And Ischyrius stresses that his comedy is 'charming' and 'pious'.

\footnotetext{
${ }^{82}$ Creizenach, Geschichte des neueren Dramas, pp. 149-50.

83 Macropedius, 'Ad pueros bonarum litterarum studiosos': Quid enim plus pueris ad eruditionem, plus adolescentibus ad honesta studia, plus provectioribus, immo omnibus in commune ad virtutem conducat quam docta comoedia?'

${ }^{84}$ Brechtus, Euripus, Prologus, 11. 14-15: 'Fructumque quicquid spiritalem fabulae / Posset [...] impedire [...]'

${ }^{85}$ Ischyrius, Homulus, 'Ad lectorem pium et candidam iuventutem: 'Habes, candide lector, comediam non minus lepidam quam piam.'
} 
Georgius Macropedius, already mentioned, wrote several biblical dramas. Besides Asotus (written c. 1507, printed 1537) and Iosephus (1544), and the allegorical Christian play Hecastus (1539), he wrote Lazarus mendicus (1541) on the parable of the rich man and the poor Lazarus (Luke 16, 19-31) and Adamus (1552). ${ }^{86}$ The latter - episodic - play shows Adam and Eve with their guardian angels. They are travelling through biblical history from the ejection from paradise to Mary's visit to her cousin Elisabeth (Luke 1, 39), awaiting Christ's birth. En passant we hear God giving the Ten Commandments to Moses, the annunciation, and the songs of Mary and Elisabeth. Macropedius's Hypomone ('Endurance', 1554) is also episodic: Hypomone and her sister Graphe ('Holy Writ') console a series of unfortunate biblical figures such as Job, the blind Tobias, the poor Lazarus and finally a group of poor students who complain about hunger and their need for books.

After he published his Omnes fabulae, Macropedius wrote Iesus scholasticus (1556) on the twelveyear old Jesus in the temple (Luke 2, 41-51). ${ }^{87}$ In the play, there are quite long monologues, prayers and lamentations of the young Jesus on his future fate. Saulus appears as Jesus' antagonist, Nicodemus and Stephanus are his followers. Unsurprisingly, it is the Christian martyr Stephanus who predicts to Jesus his passion. So it is a confessional play, but also a moral play, for instance, in the chorus of the third act, in which the audience is told to love God more than one's own parents. This play had an impact on vernacular drama. The Haarlem Rhetorician Louris Jansz. (c. 1540-c. 1604) wrote Gheestelick Spel van Sinnen seer leerlijck: Hoe Christus sit onder die Leeraers: Luce int 2. Cap. 20 (Very Instructive Spiritual Morality: How Christ is Sitting among the Scribes), printed posthumously in 1606, which closely resembles Macropedius's fabula. ${ }^{88}$

Religious drama was not the only genre written. Also school life itself was a theme for this drama. One of the first to do this in the Low Countries was, again, Macropedius. In his Rebelles (Rascals, 1535) he wrote about the 'correction' of naughty schoolboys who went astray because of the over-indulgence of their mothers. ${ }^{89}$ Not coincidentally, Macropedius published his plays, written as early as c. 1515, after his assignment as rector of the prestigious St. Jerome's school in the cathedral city of Utrecht in 1530, a centre of humanism. ${ }^{90}$ Surprisingly, however, he did so at a printer's office in his former residence, 's-Hertogenbosch.

\footnotetext{
${ }^{86}$ Full titles: Lazarus mendicus (Utrecht: Borculous, 1541); Adamus, Macropedii fabula christianae pietatis plena. In qua

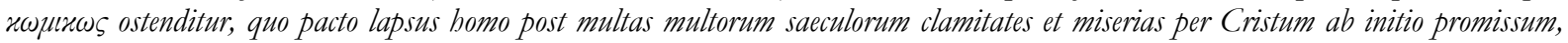
tandemque mundo exhibitum saluti restituitur in Omnes fabulae (Utrecht, Hermannus Borculous, 1552). On Lazarus, see Best, Macropedius, pp. 124-35; Giebels and Slits, Georgius Macropedius, pp. 233-40; on Adamus, see Best, Macropedius, pp. 159-65; Giebels and Slits, Georgius Macropedius, pp. 266-74; Korsten, "But did they not, with it, burn the excrements as well?'” On the edition of Omnes Fabulae, see Slits, 'Rätsel'.

${ }^{87}$ See Best, Macropedius, pp. 153-58; Giebels and Slits, Georgius Macropedius, pp. 278-85.

${ }^{88}$ On this play and another Dutch play on the same theme by Robert Lawet from Roeselaere (c. 1571), Gheestelick spel van zinnen van Jhesus ten twaelf jaren oudt (Spiritual Morality of the Twelve-Year-old Jesus), Van Gelder, Erasmus, pp. 103-04; 107-08. See Galama, Robert Lawet, Vanden verlooren zoone, pp. 17-19.

${ }^{89}$ Comicarum fabularum G. Macropedii duae, Rebelles videlicet et Aluta ('s-Hertogenbosch, G. Hatardus, 1535) and Rebelles, Macropedii fabula longe iucundissima, rudibus adbuc et tenellis Traiectinae scholae auditoribus nuncupata. On the play, see Best, Macropedius, pp. 42-53; Giebels and Slits, Georgius Macropedius, pp. 193-201; Lindeman, 'Macropedius's Rebelles and Erasmus's Principles of Education'.

90 Macropedius, Rebelles and Aluta, 'Ad pueros bonarum litterarum studiosos': 'Volebam iamdudum, studiosi adulescentes, nugas meas, quarum nonnullas ante annos viginti teneris meis auditoribus scribere coepi, [italics JB] prorsus supprimere'. Circumstantial evidence in the Apotheosis Macropedii: 'Nam vix dum coepit doctas tractare Camoenas, / Quin iuveni nimium sors cito acerba foret' and 'a ter septenis annis, podagra quia saeva / Excruciaretur'. So around his $21^{\text {st }}$ year (in 1509) Macropedius started to write poetry.
} 
It has been argued that Rebelles mirrors Macropedius's ideas about education which he borrowed from Erasmus. ${ }^{91}$ The two rascals Dyscolus ('Troublemaker') and Clopicus ('Thief') are entrusted by their mothers Philotecnium ('Child-Lover') and Cacolalia ('Curser') to the 'learned' and 'skilled' master Aristippus. According to the mothers the master is too severe, so they take their sons from the school and give them money for trading. They spend the money, and are led astray. Fortunately, in the end it is Aristippus who with his rod saves the boys. His argument is that the boys are his pupils and as such entitled to his protection. The play is interspersed with Rhetorician-like scenes in which 'sinnekens' (devils) appear; in this play they are called Marlocappus and Lorcoballus, who seduce the boys to bad habits. The play had considerable success and was printed fourteen times in the sixteenth century. It was translated into German at least twice, in 1556 and $1557 .^{92}$

Cornelius Schonaeus imitated the play some seventy years later in his Dyscoli (Bad Boys, 1603). ${ }^{93}$ In 1536 Macropedius wrote a play on the same theme, Petriscus, also with choral passages. The wise lesson is made explicit in the prologue: the play offers a beautiful example of boys learning from it 'not to wish to become friends with bad boys, but will submit to excellent teachers' ${ }^{94}$ Of course both plays are an oratio pro domo.

While these play were written with a keen eye on the pupils and education, Zovitius's Didascalus (The Teacher, 1540) in a farcically focuses on the teacher and his miserable position. ${ }^{95}$ Demus (the people) criticizes Didascalus (who is almost an allegorical figure) and accuses this despot in his black gown before a trial that is held in Breda, at which Jove is the judge, Mercury his messenger and Apollo and Minerva are members of the jury. Furthermore, some allegorical characters appear, bearing Greek names: Ablabia ('Innnocence'), Alithia ('Truth'), Glottus ('Tongue'), Colacoglottus ('Flattering Tongue'), Diabole ('Slander') and Antisilenus ('Hypocrisy'). Extraordinarily, the charge and the defence are added after the play in prose, while in the play itself, that is - as most of these plays are - written in jambs, it is indicated that 'here the charge' or 'the defence is read'. The charges are that the teacher does not understand the authors he teaches, and that he falls short in his own moral conduct. The defence stresses the parents' responsibility: they should force their children to do their homework.

Of course the humanists also wrote farces. Often these were meant to be staged at Carnival or Shrovetide, in competition with other, less decent forms of entertainment. The very first Latin play of this kind in the Low Countries is Macropedius's Aluta (1535), written and staged at approximately the same time as Rebelles, and printed together with it. ${ }^{96}$ A farmer's wife Aluta (Aleida) goes to the city market to sell some birds, but in vain. She is cheated by two villains, Harpax ('Thief') and Spermologus ('Braggart'), who 'buy' the birds without payment. Then she is going to a bar to have a drink. When she returns home, drunk, her husband Heino (Henry) does

\footnotetext{
${ }^{91}$ Lindeman, 'Macropedius's Rebelles and Erasmus's Principles of Education'.

92 Giebels and Slits, Georgius Macropedius, p. 200.

93 This play in its turn was translated into Dutch by the Delft conrector Pieter Godewyck (1593-1669) as Witte-broots Kinderen of bedorve jongelingen (White-breads Children or Spoiled Boys,1641) See Schenkeveld-van der Dussen, 'Witte-broots Kinderen van Pieter Godewyck'.

${ }^{94}$ Macropedius, Petriscus prologue, 1. 16-18: '[...] nulli velint / Rebellium parere contubernio, / Sed ptimis subesse praeceptoribus.'

${ }_{95}$ Full title: Didascalus comoedia ut doctissima, ita et lepidissima (Antwerp, Coppens, 1540; Cologne, J. Gymnicus, 1541). Modern edition by Vloeimans.

${ }^{96}$ Full title: Aluta, Macropedii fabula admodum iucunda et lepida, denuo recognita, et Traiectinae iuventuti denuo nuncupata ('sHertogenbosch: Gerardus Hatardus, 1539); a modern edition by Bloemendal and Steenbeek; on the play, see, for instance, Giebels and Slits, Georgius Macropedius, pp. 188-93.
} 
not know what to do. He sends his son Paedium ('Child') to get the priest Mystotus ('Complete Mystery') who 'exorcises' the devil of drink:

In nomine patris atque filii, sacri

Quoque spiritus cede, maledicte diabole,

Ab hac Dei famula et da honorem illi Deo,

Qui iudicare mortuos venturus est / Vivosque per flammam!

(In the name of the Father, and the Son, and also of the

Holy Spirit, begone, you wicked Satan, from

This servant of God and give honour to the God

Who will be coming to judge the dead

And the living through fire! $)^{97}$

The priest - it is to note that the Church brings salvation - then invites the husband Heino for a drink. The Grex of all players then gives the moral: don't drink too much, and don't cheat or steal. The drinking and eating scenes suit the Carnival aspect of the play, as well as the chorus of Mardi Gras celebrants. Another chorus, consisting of farmers' wives from Bunschoten (a village some 30 kilometers from Utrecht), gives a moral counterbalance of moral lessons: a warning against parasites, a repudiation of innkeepers, a warning against marrying a drunken wife, or a stupid one.

Macropedius wrote two other Shrovetide plays: Andrisca (Virago, 1538) and Bassarus (1540). ${ }^{98}$ The plot of Andrisca combines two medieval farces, the Cluyte van Playerwater (Farce of Playwater) and Moorkensvel (The Black Horse's Skin). In the Latin play, Porna, the wife of the currier Byrsocopus ('Tanner') is sewn into a horse's skin (like in Moorkensve) as a punishment for her love-affair with a local priest Hieronymus ('Holy Name'). She can have her way by sending her husband to get her 'playwater', which has to be got from the far East. They are the neighbours of Andrisca, who is addicted to the wine and her husband Georgus ('Farmer'). Georgus beats his wife to bring her to her senses again. It fits in a time when circumstances are changing from the extended family to the nuclear family and the 'battle for the trousers' is fought.

In Bassarus by the same author, it is the village sexton Bassarus ('Fox') who has cheated the vicar and the bailiff and invites them to dinner. The Argumentum summarises what follows:

Custos paroecho praesidique Bassarus

(Quod sordidi essent et tenaces plurimum)

Lepidis dolis cum obsoniis vina abstulit

Et ad illa edenda eos vocavit vesperi,

Adiutus infidelitate Creobori et

Larvis suorum liberorum Bacchicis.

Fit interim ob tenebras, tonitru et fulgura,

Primum paroecho sacram ad aedem territo,

\footnotetext{
${ }^{97}$ Macropedius, Aluta, 11. 529-33.

${ }^{98}$ Georgii Macropedii Andrisca fabula lepidissima ('s-Hertogenbosch: Gerardus Hatardus, 1538); Georgii Macropedii Bassarus, fabula festivissima ('s-Hertogenbosch: Gerardus Hatardus, 1540); modern editions by Leys and Engelberts. On the plays, see Best, Macropedius, pp. 76-90 and 92-107 resp.; Giebels and Slits, Georgius Macropedius, pp. 208-15 and 21522 , resp.
} 
Dein Creoboro a cruce persequente aerario, Spectaculum lepidissimum. Post Bassarus

Sua singulos cena soluta obsonia

Magno omnium risu comesse disserit.

(The sexton Bassarus has stolen meat and wine

From the vicar and the bailiff, in a funny way, Just because they were too miserly and stingy.

At night he invites them for this very meal

With the help of the treacherous Creoborus and

The Carnival masks of his children. In the mean time

Because of darkness, thunder and lightning

Something joyful can be seen: first the vicar is chased away

From the church, after that Creoborus from the gallows,

Hunted by the coppersmith. Finally, when dinner is finished,

Bassarus cheers up everybody by telling them that they

Just ate their own food. $)^{99}$

A distinctive feature of Bassarus is the organisation of the choruses. All four odes have the same form and three strophes. The first three odes denounce gluttony, greed and ambition respectively, while each stanza of the fourth ode praises the opposite of these vices as wise. ${ }^{100} \mathrm{~A}$ second distinctive feature of the play is the use of the vernacular for comical purposes. The parasite Creoborus asks the coppersmith, in Latin and Dutch: 'Adhunce vivis, Heino? Hein lefdi noch?' ('Hein, are you still alive?'), and gets the answer: 'Quis necuerit? Wie solt my doot hebben?' ('Who would have killed me?'). ${ }^{101}$ With the masks, the moralisations and the festive dinner Bassarus is every inch a Mardi Gras play.

These plays were related to religious or ecclesiastical issues, but the next play treats a classical subject only. It was written by the rector at the Latin school of Gouda Petrus Nannius (or Nanninck, 1500-1557), who had studied at Leuven University and would become a professor at the Collegium trilingue. The comedy is called Vinctus (Bound, 1522). It is a bourgeois love comedy with a setting in Antiquity and a plot borrowed from comedies by Plautus and Terence, especially Casina, Andria and Eunucbus. Unlike his predecessors, Nannius wrote his play in prose. Maybe he got his inspiration from the 1481 Leuven Declamatio or - more likely - Dorpius's Dialogus. ${ }^{102}$ $V$ inctus, however, had no response: it has not been translated or imitated, and only two copies of it have survived.

Perhaps the same Dialogus in combination with a folk tale inspired Johannes Placentius, who also had studied in Leuven, to write his Lucianus aulus and Clericus eques (A Priest on Horseback, 1535). ${ }^{103}$ These plays are written in prose like Dialogus and Vinctus. Clericus eques consists of three acts. It may be based on a medieval story or on a fable by Heinrich Bebel (1472-1518) or a story

\footnotetext{
${ }^{99}$ Macropedius, Bassarus, Argumentum.

100 Observed by Best, Macropedius, p. 94.

101 Macropedius, Bassarus, 1l. 774-75.

102 See above, p. \#.

103 The latter play was the subject of an unpublished BA-thesis at the University of Amsterdam by Stijn Buiter, 2007.
} 
by Johannes Pauli (1455-1530) in his Schimpf und Ernst. ${ }^{104}$ The plot of the play centres on a misunderstanding. The poor cleric Clericus, coming from Paris, cheats a woman, Columbana ('Little Pigeon'). When she asks him where he comes from, she believes he says: 'From Paradise'. Perhaps, she thinks, he will know something about her deceased first husband. Clericus of course has some information: her husband needs clothing and money, and he, Clericus, can bring them to him. She gives him the expensive coat of her second husband, Oenophilus ('Lover of Wine'). The man chases the cheating cleric, but in the third act the same cleric steals his horse. The play ends with a drinking-bout of Oenophilus, a bailiff and a farmer.

This was not the first medieval subject treated. The Ghent scholarchus (school leader) Eligius Eucharius or Elooi Hoeckaert, who had been educated at Paris, took as a subject for his Griseldis (1512) one of the well-known stories of Boccaccio's Italian Decamerone about a prince who tests the faithfulness of his wife that was retold by Petrarch in Latin. ${ }^{105}$ Eucharius added the names and place of origin of the boys who were actors in the play to the printed text. He expressed his humanistic position in an original way at the beginning, where the margrave of Saluzzo praises hunting above all other pleasures: some people love drinking, others finery or reading bad books like the pseudo-ovidian Vetula and the Pamphilus. Griseldis is very well-behaved, warning her husband that they should not be led by greed, but by chaste love, the decent spirit that dispelled Asmodeus to Egypt, as was told in the book of Tobith. ${ }^{106}$ The same Eucharius performed several plays at his Latin school in Ghent, including ancient comedies, Plautus's Captivi and Stichus, as well as modern dramas: a French comedy Veterator by Alexander Connibertus, Sergius by the German author Reuchlin, and Dolotechne by the Italian writer Bartolomeo Zamberti and other Italian plays. ${ }^{107}$

Another medieval farcical play is the 'witty dialogue, divided into acts like a comedy' Pisander bombylius (1540; repr. 1546) of Arnoldus Madirus (16 ${ }^{\text {th }}$ c.). ${ }^{108}$ This is a very short play in prose, for merely four characters, situated near Mechelen. A farmer complains that he is strongly controlled by his wife. Now she has gone to the market and she told him to stay home and milk the cow. On returning home she tells him that soldiers are nearby. The farmer puts on a copper pan for a helmet and a rusty cuirass that had been used to collect muck. When the soldiers arrive to steal some chickens, the farmer appears fully dressed and shouting with fear. Then the plunderers think they see a ghost and flee. Of course, the farmer, when in the fifth act he puts his head out of the hen-house (e gallinario capite exerto), is sharply criticized by his wife. She herself claims the victory over the enemies because of her verbal approach. She says that henceforth she will call him Pisander Bombilius, because he behaved more cowardly than Pisander but boasted like a

\footnotetext{
104 On Bebel, see $A D B$ and NDB, s.v. (Ludwig Geiger and Heinrich Grimm), on Pauli ibidem (Hermann Oesterley and Walter Ernst Schäfer). On the relationship between Clericus eques and Bebel, see Stiefel, 'Der "Clericus Eques" des Johannes Placentius und das 22. Fastnachspiel des Hans Sachs', pp. 440-45.

105 See Grypdonck, 'Eligius Houckaert'; Vroomen, '8 september 1512'; the theme stayed en vogue: a Wallonian Augustinian, Michael Hoyerus, adopted the theme of Grisellis in his Historiae tragicae, see IJsewijn, 'Theatrum BelgoLatinum', p. 88; a facsimile of the programme of a 1775 performance of a Grisellis is printed ibidem, pp. 111-14. The play was printed in Ghent, in 1516.

106 '... ne nos pecuniae libido / Exagitet, sed amor castus, qui pignora sera / Matribus annosis tribuit; nos spiritus ille / Ducat, qui Asmodeum connubia casta perosum / Extremae Egipti vasta conclusit eremo.' See also Creizenach, Geschichte des neueren Dramas, pp. 53-54.

107 See IJsewijn, 'The Coming of Humanism', pp. 279-80.

108 Arnoldi Madiri Pisander bombylius. Dialogus iocularis, per Actus in modeum Comoediae distinctus (Antwerp: Ioannes Steelsius, 1540). See Creizenach, Geschichte des neueren Dramas, pp. 160-61.
} 
loudly buzzing bee. ${ }^{109}$ The play was printed in 1540 , and must have been written after 1536, for in the fourth act the soldiers allude to ordinances of Mary of Hungary on 21 July and 21 October of that year. ${ }^{110}$ The play had some success and was staged in Ribe in Denmark (Jutland) in 1576.

The first generation of Latin playwrights in the Low Countries performed ancient comedies and also wrote other plays on biblical stories, or on classical or medieval subjects, as a logical consequence of their interest in classical drama. The classical plays formed a limited arsenal, but by making plays themselves they could add moralising and other edifying remarks, serve their own literary aspirations, and develop other biblical and religious themes. It was not so much out of 'an explicit critical approach towards classical literature' - why would they have added so many licentious scenes in their dramas - but to serve their educational principles. ${ }^{111}$ They still felt the need to defend themselves for writing and staging comedy. This was related to recent school reforms as the medieval inductive method gave way to the humanist deductive one. Moreover, the authors were finding the form, still mixing dialogue and comedy, or employing classical, medieval and Rhetoricians' forms and themes. The plays were written in an age of religious unrest, in which the first executions of heretics took place. The Low Countries still formed a political union, under the Spanish Habsburgs. In this first half of the sixteenth century the writing of Dutch Latin drama was at its height, with Brechtus, Zovitius, Crocus, Gnapheus and, above all, Macropedius.

\section{The Second Generation - Maturity and Confessionalizaton (1550-1600)}

Around 1550 the first generation of Neo-Latin playwrights in the Low Countries died or stopped writing. The next generation trod in the footsteps of their forerunners and continued the tradition, but it also went its own ways. This had to do with the acceptance of Latin comedy in society and the process of confessionalization and the division of the Low Countries. Even though the subjects were approximately the same, as well as the form - in general -, the way of treating them differed.

For instance, although the Haarlem rector Cornelius Schonaeus based his Iosephus (1592) on the play written by Crocus, he differed from his predecessor in giving a typological explanation and another moral-ethical one. ${ }^{112}$ Just like Crocus Schonaeus stressed Joseph's constancy, the same constancy as was seen in Christ, and his ability to endure all blows bravely and with equanimity. However, this constancy is more elaborated and more accommodated to Stoic philosophy. In his elaboration of Stoic calm, Schonaeus belongs to the second stage of Latin drama in the Low Countries. In 1578 he had seen the 'Haarlem None', when the St. Bavo was attacked by Protestants and soldiers of William of Orange, and also other blows had taken place, with which people had to cope. Another distinctive feature of his Joseph play is the introduction of amatory

\footnotetext{
109 Ed. Antwerp (Ioannes Steelsius), 1546, fol. B3*v: 'Quia Pisandro stupendae timiditatis homine quum sis formidolosior, ad instar bombylii magnifica iactitasti, et lingua quidem bellasti gnaviter, sed ubi res ipsa tuam posceret iactitatam audaciam, ne my quid hiscere audebas.' The Athenian politician Pisander often was attacked in comedy for corruption and cowardice.

${ }^{110}$ Ibid., fol. Bv: 'Primum quanto plausu noster ubique exceptus adventus est! Verum quantis statim in Reginae aula actum querelis, de nostris illatis iniuriis; nec cessatum donec publico edicto cautum sit, ut ab iniuria temperemus, capitis supplicio transgressori interminato'. See IJsewijn, 'Theatrum Belgo-Latinum', p. 74 and n. 8.

111 Parente, Religious Drama and the Humanist Tradition, p. 7; cf. Verweij in Vladeraccus, Tobias, p. 17.

112 See the introduction to the edition of Iosephus by Bloemendal and Groenland.
} 
language from Ovid and Terence into his charactization of the seductive wife of Potiphar. Of course, in the end the Christian values dominate the scene. Thus, the superiority of Christianity and Christian constancy - to pagan Antiquity and its concept of constancy could be shown. Also in this second period allegorical drama became a less pronounced part of dramatic production.

Circumstances also changed. From 1568 onwards the Dutch Revolt gradually resulted in a separation of the northern and southern provinces, beginning with the Unions of Arras (or Atrecht) and Utrecht (1579). Now the southern provinces united with Catholic Spain, and the northern provinces opposed it. In 1581, with the proclamation of the declaration of independence or the Act of Abjuration, in the northern part the Dutch Republic or the Republic of the Seven United Netherlands was established. Borders changed, but were fixed in 1609 at the Twelve Years' Truce. The southern provinces remained in Spanish hands. Many Protestants fled from the south to the north, which resulted in a re-catholisation of the southern provinces, and a further protestantisation of the northern ones.

The establishment of the Jesuit order turned out to be another decisive changing circumstance. Founded in 1534 and approved in 1540, the Societas Jesu soon became one of the major orders, directed at education and mission. ${ }^{113}$ Many Jesuit colleges and gymnasia were founded, at which practical exercises were an integral part of the curriculum. These exercises included the staging of theatre plays. In the Low Countries (in Jesuit terms the Flandro-Belgian and Gallo-Belgian Provinces), where the first Jesuits arrived in the summer of 1542, the Order established its first settlement in Leuven in 1547, which became an official noviciate in 1560. Between 1560 and 1580 members of the Company of Jesus founded schools in Tournoy, Dinant, Cambrai, St. Omer, Douai and Liège, and in Maastricht, Antwerp, Bruges and other places. After the Pacification of Ghent (1576) the Jesuits had to leave many places, to be able to return only after the military successes of Alexander Farnese (1545-1592). They could create new colleges in the Flemish towns Ieper, Courtroi, Ghent and St. Winoksbergen, between 1585 and 1600. In the seventeenth century the establishment of schools did not come to an end in the Southern Netherlands, but in the Protestant northern provinces they had hardly any success. In the highly urbanised South, the colleges were a substitute for already existing centres of education, where pupils could be oriented to Catholic piety and drenched with bonae litterae. Education was free, so the Order reached every social class.

In spite of these ever changing political and religious circumstances, Latin drama was written and staged. A fine example is Cornelius Schonaeus or Schoon (1540-1611). ${ }^{114}$ Born in Gouda, he was educated in Leuven and finally became a rector of the Latin school of Haarlem. It is telling for the qualities of the Catholic rector and his fame, that after the alteration of Haarlem in 1578 from Catholicism to Protestantism, he kept his position. This may also attest to the fact that religious quarrels could be fierce, but not totally dominating in every city or town. Schonaeus's first source of inspiration were the plays by Macropedius, one of which he he saw performed in 1552. Schonaeus became a very prolific author of thirteen biblical dramas (comoediae sacrae) in which he treated themes from the Old Testament (Naaman, Joseph, Judith and Daniel) from the New Testament (the conversion of Paul, the healing of one who was born blind, Ananias, John the Baptist, the resurrection, and Pentecost), and the apocrypha (Nehemia, Tobias and Susanna).

\footnotetext{
113 See also the contribution by Fidel Rädle, pp. \#. On Jesuit drama in the Low Countries, see Van den Boogerd, Het Jezuïetendrama in de Nederlanden, McCabe, An Introduction to the Jesuit Theater, Proot, Het schooltoneel van de jezuïeten in de Provincia Flandro-Belgica.

114 An extensive biography and bibliography were made by Hans van de Venne, Cornelius Schonaeus.
} 
Furthermore, he wrote three farces (fabulae ludicrae), a school comedy (comoedia nova) Dyscoli, that was inspired by Macropedius's Rebelles, and a lottery play (Fabula comica). The play last mentioned - and actually Schonaeus's last play - was written for the great Rhetoricians' contest held in Haarlem in 1606. A pirated edition of four of his plays in Keulen in 1591 had the title Terentius Christianus, which was the first of a series of editions with the same title. This established his name as 'the Christian Terence'.

Schonaeus had made his debut in 1569 with Tobaens, based on the apocryphal book Tobith. There it is told how the pious Tobith becomes blind. He has sent his son Tobias on a dangerous journey, accompanied by Azarias, who actually is the archangel Raphael. While bathing, Tobias is menaced by a big fish; his companion orders him to catch it and to preserve the liver and the gallbladder. Finally, Tobias smears the fish's gall on his father's eyes, and he is cured. After that the angel Raphael makes himself known and disappears. It was a consoling story about God changing misfortune into fortune. Moreover, the story was suited to comedy, because in the original version admonitions and expositions on conjugal ethics and poor relief were intertwined. Often the story was understood as a journey of the soul to God, or Tobias, who cured his father, was seen as a prefiguration of Christ. Finally, the story consoled travelling merchants. In the 'Peroratio' (Epilogue) to the play, Schonaeus gives his own interpretations of the story. $\mathrm{He}$ stresses - again - the father's Stoic calm in difficult circumstances from the conviction that God will turn seeming troubles into blessings, and he summons the youth to chastity and aversion to wantonness ('lascivia'), leaving aside typological exegesis. ${ }^{115}$ The play had a tremendous success, and was printed over 50 times, and translated into English, German, Danish and Polish. Moreover, it was performed, for the first time on 24 June, the feast of Corpus Christi, 1568.

Schonaeus's plays were rather popular. The Juditha and Joseph that in 1597 were performed in Utrecht, the Netherlands, would have been his, as would the Daniel that students in the province of Groningen staged in 1617. To modern eyes, they lack action, but his contemporary audience clearly had other interests. ${ }^{116}$

The Fabula comica is a rather special case in the history of Dutch Latin drama. Schonaeus had Dutch 'Prefaces and interludes' ('Voor-reden ende tusschenspraken') added, written by himself or, more likely, by one of the Haarlem Rhetoricians. ${ }^{117}$ This was a service to the members of the audience who did not know Latin. It was necessary to reach as many people as possible since the object of the Rhetoricians' contest was to raise money for an old people's home. This play consists of many conversations on giving alms to the poor on the basis of practical and biblical arguments, and has little or no action. The play opens with a monologue of Theophilus ('Lovedby-God' and 'Loving God') saying that he is glad he never considered giving alms a waste of money:

Gaudeo me iam inde ab adolescentia fuisse eo

Animo, ut nihil minus putem perire, quam

Quod confertur in egenos, atque pauperes:

Tales potissimum qui aetate infirmi, ac debiles,

Domi insuper ringuntur, et cruciantur inediâ.

In horum subsidium ego lubenter aliquid confero:

\footnotetext{
115 Thus, he could avoid to get into religious quarrels.

116 See Verweij, 'The Terentius Christianus at Work'.

117 See also Van de Venne, Cornelius Schonaeus, 1 Leven en werk, p. 242-44.
} 
Neque id perire, sed in ipsum Deum erogati existimo.

Quando ipse Christus, nostrae auctor salutis, indigenter

Et fortunae tenuioris homines tam sedulo

Commendarit nobis: manifestis verbis afferens: id quod

In pauperes confertur, in

Se esse collatum: atque huius beneficii nequaquam

Se immemorem fore.

(I am glad that from my early years on I tended to consider nothing is a lesser waste of money than what is collected for the poor and the needy, especially for people who are sick and tired by old age and are sulking and suffering from famine at home. To help them, I am happy to contribute something. To me, that is no waste, but spent for God himself, since Christ, our Saviour, recommended our poor and unfortunate neighbour to us, when He clearly stated that what was given to the poor, was given to himself and that he would never forget such charities. ${ }^{118}$

A similar technique was employed by Cornelius Laurimanus, Laurimannus or Lauwerman (c. 1520-1573) in his Miles Christianus (1565). ${ }^{119}$ This playwright was taught by Macropedius in Utrecht and studied in Leuven, probably law. He became the successor of Macropedius as the rector of the Utrecht St. Jerome's school. Utrecht had a special position in the Republic, since it was a Catholic enclave in a Protestant country until its alteration in 1580. This situation brought problems to the school, for connections with the Brussels and Madrid authorities were hard to maintain and fewer pupils attended the lessons.

Laurimanus took the abilities of his audience into consideration. The second choral song of his play Miles Christianus, taken from Psalm 26, is sung by the Christian soldier in Latin, while the allegory of Scripture repeats the same song in Dutch. In this play Laurimanus represented the Christian soldier, a metaphor from Ephesians 6, 10-17, made famous by Erasmus in his Enchiridion militis Christiani (Manual, i.e. handbook and dagger, of the Christian Soldier, 1503). The play in which allegories figure only, for instance Pistis, Elpis and Agape (i.e. Faith, Hope and Charity), Graphe (Scripture) and Hypomone (Endurance), focuses on the struggle against heresy, for which the armour of God must be used. ${ }^{120}$

In the same vein Laurimanus explained the story of the Israelites' exodus from Egypt in his Exodus (1562). ${ }^{121}$ In the 'Epilogus seu Peroratio' he tells the audience that the Israelites represent the Catholic Church, which is continually attacked by the pharaoh, i.e. the Lutheran heresy. The epilogue summons Christian rulers to protect Catholicism.

A similar exegesis was attached to Laurimanus's first play, Esthera Regina (1560) that was performed at the occasion of the consecration of an extension of the Utrecht Buurkerk. ${ }^{122}$ The story of Esther who marries King Ahasveros to replace Vasthi and saves the Jewish people against the king's general Haman shows the 'fickleness of human life' ('mutatio rerum'), warns against pride and praises humility. The fortune of Haman shows that pride goes before a fall.

\footnotetext{
118 Schonaeus, Fabula comica, 11. 1-13. : 'The reference is to Matthew 25, 40 and 45.

119 On him and his plays, see Bloemendal, 'Cornelius Laurimanus als Dramatiker'.

120 On this play, see Bloemendal, 'Cornelius Laurimanus als Dramatiker', pp. 123-29.

121 Ibidem, pp. 117-23.

${ }^{122}$ Ibidem, pp. 109-17 and Steven Leefers, 'De Esthera Regina van Laurimanus' (unpublished BA thesis).
} 
These interpretations were given to the spectators and the readers in the Prologue. In the Epilogue again a typological-anagogical exegesis is given: Ahasveros represents Christ, who repudiated his first wife Vasthi, i.e. the Jewish people, to marry another one, Esthera or the true Catholic Church which God had created for man's salvation. The pupils should stay with Esthera and, he implies, not adhere to any heresy. ${ }^{123}$ Laurimanus's plays seem to be the last convulsions of a Catholic in an ever more Protestant, hostile world. The mutatio rerum may be wishful thinking for a return to Catholicism.

The Utrecht canon Philippus Morus (d. 1578) also wrote some plays: the 'tragicomoediae' Naboth (1571) on the vineyard of Naboth taken away by king Achab and his wife Jezebel by having him stoned (1 Kings, 21) and Vinea Christi (1578), both preserved in manuscript. ${ }^{124}$

Laurimanus was a Catholic teacher in the northern provinces. In 1544 a canon and teacher in the southern provinces, Petrus Philicinus, Félicinus or Pierre Campson (c. 1515-after 1574) already had written a play on the Esther theme, Tragoedia Esther sive Edissa, in 1544, which, however, was published only in 1563, dedicated to Bishop Gerard of St. Omer. ${ }^{125}$ In the letter of dedication he explains the typological interpretation he wants to give this play, Esther being a prefiguration of the virgin Mary. This play is special, since it is one of the first tragedies in the vein of Seneca written for the Latin school and not for university. It also bears some features of Roman comedy; for instance, it is concluded by a 'Peroratio' in which the explanation is given: the faithful suffer misfortune not by mere chance, but with God's approval. By such adversities God wants to bring them to repentance and strengthen their faith. If faith deepens, God will bring salvation. ${ }^{126}$ In another play, Dialogus de Isaaci immolatione (1544), Philicinus extensively explained the christological significance of Abraham's sacrifice of Isaac (Genesis 22, 1-19), prefiguring God's sacrifice of his Son. ${ }^{127}$ On a tropological level, Isaac represented utter obedience and trust in his father and - on the typological level - in God. In the preface to his other play, Magdalena (1544) he states that he took the licence to employ religionis nostrae vocabula. The main focus is on the dialogues of Mary.

Somewhat special is the Pornius (1568) of Hanardus Gamerius Mosaeus (Van Gameren, fl. 1550s-1570s). In 1566, at the time his drama was successfully staged both in Amsterdam and in Landshut, he was a professor in Ingolstadt, where he was active as a humanist and a polemicist for the Counter-Reformatory cause. ${ }^{128}$ Duke Albert of Bavaria had encouraged him to do so. But when Jesuits took over the university of Ingolstadt, he returned to the Low Countries, where he became rector of the Latin school at Tongres and, in 1571, in Harderwijk in Gelderland. From 1576 he was an apologist of Don Juan of Austria, by then governor of the Netherlands for Spain. Pornius, tragoedia vere sacra ('Wanton man, a Truly Holy Tragedy') was written for the defense of the Church. The morality play is an imitation of Brechtus's Euripus (without acknowledging his debt), though he does not employ the theme of the narrow path and the broad way. It does present the choice of Pornius between Virtue and Theophilus on the one side, and Voluptas, Amor and

\footnotetext{
123 On Esther on the stage, see, for instance, Washof, Die Bibel auf der Bühne, pp. 114-40.

124 A facsimile of the Naboth ms in Geurts, DE Utrechtse kanunnik Philippus Morus.

125 A new edition in Philicinus, Esther, ed. by Bloemendal and Groenland.

126 On the tension between tragic and Christian worldviews, see below, p. \#.

${ }^{127}$ Petrus Philicinus, Dialogus de Isaaci immolatione ad puerilem captum accomodatus (Antwerp, Ioannes Steelsius, 1544). He also wrote a Magdalena evangelica that he had written in jambic dimeters and that was shaped into the form of a comedy and published in Antwerp, 1544, see Hugo Holstein, ADB, 25, p. 742.

128 Creizenach, Geschichte des neueren Dramas, p. 145-46; Rice Henderson, 'Humanism and the Humanities', pp. 164 and 165-66.
} 
Venus on the other. Eventually Venus wins by flattering him like a meretrix in Roman comedy. The tragic catastrophe occurs when Pestilentia appears on stage as a precursor of Mors, and in the fifth act the audience sees the damned soul of Pornius in hell. In this second phase plays apparently are often more polemical than in the first.

Polemical, too, is Evangelicus fluctuans (1569) of the Leuven professor and Catholic theologian Andreas Fabricius (André Lefèvre, 1520-1581). ${ }^{129}$ This play served the Counter-Reformatory cause as well, visualising the differences between the wandering Protestant heresies and the Catholic faith that is the only means to salvation in a struggle of Virtues and Calumnies. ${ }^{130}$ This is epitomized in the figure of the 'Wavering Christian', looking for an orientation in the confessional confusion of his age. He goes from one heresy to the other, until he finally retrieves the ancient religion through Catholicus and Sapientia. They are opposed by 'Pandora Meretrix Babylonica' (the whore Pandora) and her servants Cupid, Tehomachus ('Fighter against God'), Curiositas and Calvinus. ${ }^{131}$ At the end of the play, the Church gains the victory.

Fabricius wrote three other, similar plays, Samson (1569), Jerobeam rebellans (1585; on Jerobeam rebelling against King Solomon, 1 Kings 11, 26-40) and Religio patiens (1566). ${ }^{132}$ In the latter play, too, the woes of the age and the main causes of the Church's suffering are revealed. ${ }^{133}$

This generation also produced another kind of drama: hagiographic plays. The Liège theologian and humanist Gregorius Holonius or Grégoire de Hologne (c. 1531-1594) published three of these martyr plays in 1556: Catharina, Laurentias and Lambertias. ${ }^{134}$ These Senecan plays, that appear to have been originally written for the 'Gymnasium Bartholomaeanum', seem to have had some success on German Jesuit stages. ${ }^{135} \mathrm{He}$ considered the martyrs as Christian substitutes for the immoral characters of Graeco-Roman drama, especially those of the pseudo-Senecan Octavia. Moreover, stressing the heroic qualities of the martyrs, he showed the audience examples of Christian heroes who fought for Catholicism, against the 'seven-headed dragon of heresy'. ${ }^{136}$ Holonius thus presented the third-century martyr St. Laurence of Rome who was burned to

129 See on him, e.g., Valentin, Les jésuites et le théatre, p. 240; on Evangelicus fluctuans, see Janning, Der Chor im neulateinischen Drama, pp. 219-22; Rädle, 'Frischlin und die Konfessionspolemik im lateinischen Drama des 16. Jahrhunderts', pp. 516-17; Creizenach, Geschichte des neueren Dramas, pp. 146-47.

${ }_{130}$ Already the title shows the content and the intention of the play: Evangelicus fluctuans, tragoedia, qua propostio erratici hominis paradigmate, haeresum vanitas, haereticorumque fraudes percurruntur, ac simul clarum efficitur, non esse ulli spem aeternae salutis relictam, qui coetui Catholiciorum se non aggregarit, quibus scilicet hoc proprium est, u doctrinae suae originem ad Apostolos, virosque apostolicos, per continuatam temporum seriem referre possint ('The Wavering Evangelical, a Tragedy, in which the Example of an Erring Man is Shown, and the Vanity of the Heresies and the Tricks of the Heretics are Told, and in which it is Made Clear as well, that there is no Hope for Eternal Salvation Left for him who has not Joined the Congregation of Catholics, who can Trace Back the Origin of their Doctrine to the Apostles and Apostolic Men in a Continuous Series of Time'), Cologne 1569.

${ }^{131}$ Fabricius apparently uses a common metaphor for the Catholic Church, the Whore of Babylon, for the opposite party.

132 On Samson, see Valentin, Les jésuites et le théâtre, pp. 239-44.

133 See Janning, Der Chor im neulateinischen Drama, pp. 216-18.

134 Antwerp: Ioannes Bellerus. The full titles run: Lambertias. Tragoedia de oppressione B. Lamberti Trajecten[si] quondam ecclesiae, quae nunc Leodium translata est, episcopi et martyris gloriosissimi (Lambertias, tragedy on the affliction of St. Lambert of Maastricht, once bishop of the church that is now transposed to Liege and a most glorious martyr); Laurentias. Tragoedia de martyrio constantissimi levitae D. Laurentii Romae sub Decio passi (Laurentias, tragedy on the martyrdom of the most perseverant priest Laurence, who sufffered in Rome under Emperor Decius); Catharina. Tragoedia de fortissimo $S$. Catharinae virginis, doctoris et martyris certamine (Catharina, tragedy on the couragious struggle of St. Catharine, virgin, teacher and martyr). The titles Laurentias and Lambertias in epic manner end on -as.

135 Parente, 'Counter-Reformation Polemic and Senecan Tragedy', pp. 176-80. His plays were performed and imitated by German Jesuits. Many colleges had a copy of the three plays, and at least two of them (Lambertias being of mainly local significance) were quite popular.

${ }^{136}$ Holonius, Laurentias, fol. Aiiv: 'Hydram illam haereseos septicipitem'. 
death, St. Catherine of Alexandria who was bound to a wheel, and the sixth-century legendary founder of Liège St. Lambert as prototypes for Counter-Reformation defenders. ${ }^{137}$ This was suitable for a school in Liège, which was a stronghold of Catholicism, and Holonius's plays must be viewed within the context of the Counter-Reformation. Holonius's bishop Lambert warns, like John the Baptist, his sovereign against adultery and died through the machinations of the offended woman. But there is more. His St. Catherine who used theology, philosophy, history and natural science to demonstrate the validity of Christianity was a model of the education of future priests. Even though all the protagonists obtain eternal life, Holonius called his plays 'tragoediae'. He sought to emphasize the dreadful death by the pyre. The plays, however, can also be seen as a kind of 'mirror of princes'. Each of the three plays was dedicated to one of the three sons of Count Charles de Berlaymont, general of Charles V in the campaigns against the French, who had appointed Holonius as their tutor.

Just like the first generation, this generation turned to classical literature and translated Greek plays. Georgius Ratallerus (1521-1581) published translations of the extant tragedies of Sophocles: Tragoediae Sophoclis quotquot extant (1570). Fourteen years later he added three plays by Euripides: Phoenissae, Hippolytus and Andromache (1584). Here, too, there is a difference between this generation and the first. Tiara had called Euripides's Medea a fabula, while Ratallerus talks about tragoediae. ${ }^{138}$ In the next generation, Hugo Grotius would try his hand at Phoenissae again (1630), thus ending the Dutch highly esteemed tradition of translations from the Greek.

Greek comedies were translated into Latin, too. Between 1556 and 1651 the Naarden rector Lambertus Hortensius or van de Hove (1500/1501-1571) of Montfoort published his translations of Aristophanes's Plutus, Nebulae, Ranae and Equites. A Latin version of Plutus had been previously published in 1533 by Adrianus Chilius (d. 1569) from Maldegem. ${ }^{139}$

The interest in classical material also increased in the choice of subjects of some authors. The Flemish poet Petrus Ligneus or Van den Houtte (b. c. 1520) from Grevelingen wrote a Dido drama (1559). The opening resembles some of Seneca's tragedies and shows Fury rise from hell: Adsum Tartareis Furiarum maxima claustris, while in the Dido tragedy by Aulus Gerardus Dalanthus from the North-Brabantic Heusden (d. 1577), published in the same year, it is Venus who opens the scene: Herbosa linquens Ideali viridis inga / Adsum Venus. The subject, taken from Virgil's Aeneid IV, is a tragedy in itself: the Phoenician queen of Carthage, Dido, falls in love with Aeneas and commits suicide when he abandons her. In the seventeenth century the Leiden professor Petrus Cunaeus (1586-1638) made his own version, that was quite faithful to the original. ${ }^{140}$ Another mythological theme was taken up by the sixteenth-century Frisian poet Theodorus Euroteles (from Oosterend near Bolsward) in his Indicium Paridis (1574) that is now lost. Interest in Greek literature is also attested by renderings in Latin of Greek plays.

\footnotetext{
137 As Parente shows, Religious Drama and the Humanist Tradition, pp. 45-46, Holonius opposed to the fictionality of Seneca's terrifying plots, and 'was eager to replace the immoral mythological tales of Seneca with a pantheon of historical Christian heroes.' Cf. Holonius, Catharina, fol. Ciiv-Ciiir: 'Nullum deorum numen esse in fictili, / Nec magis in auro muscido, quam stipite / Dignum supremo qui Deus colitur locum [...] / Turbam deorum et inde vestrorum nego, / Numinaque ficta mille, tercentum Ioves: / Patres, sorores, coniuges et pellices, / Natos, parentes, et procul ab atavis genus, / Infame stupris unde coelum fluctuet.'

138 Some of Ratallerus's translations would be included into the volume Tragoediae selectae Aeschyli, Sophoclis, Euripidis (Paris, Henricus Stephanus, 1567)

139 The editio princeps of the Greek text of Aristophanes's comedies had been published by Aldus Manutius in Venice, 1498.

140 Edited by Heesakkers.
} 
Towards the end of the century, the Catholic cleric, humanist and teacher at the 'sHertogenbosch Latin school Petrus Vladeraccus (1571-1618) wrote, staged and published his Tobias (1598). ${ }^{141}$ Vladeraccus, brother of the common life and writing in the style of his precursor Macropedius - including the use and the form of chorus songs - presents the story of Tobias, and applies it to two major themes, continentia and patientia. ${ }^{142}$ In this play, he resumed a story that had been put on the stage by Schonaeus thirty years earlier. Vladeraccus, however, was more inspired by the plays of Macropedius. ${ }^{143}$

Tragedy was a literary genre, but also a genre that could be employed in topical issues. Ioannes Baptista Gramaius or Jan-Baptist Gramaye (1580-1635) ended the century at the Joyous Entry of Albrecht and Isabella in Leuven, in November $1599 .{ }^{144}$ At this entry a wagon featuring Perseus and Andromeda was placed at the end of the procession, with signs attached containing verses that gave an allegorical explanation: Andromeda symbolised the Netherlands, saved by Perseus, i.e. Albrecht, riding on the horse Pegasus, who represented Isabella. The sexual connotations of course were diligently withheld. On the occasion pupils of the Pedagogy 'The Porc' with their young professor of rhetoric Gramaye performed a Latin 'tragicomedy' Andromede Belgica dicta, which was interpreted in the same allegorical way.

This second generation was slightly less prolific than the first, and fewer authors made names for themselves abroad. The notable exception was Schonaeus, who was a productive and a prolific author. In some cases they took up subjects of the first generation or imitated them. Yet, they also differed in their approach, by adopting a more Stoic-Christian worldview in some plays. In the writing of tragicomedies, Senecan patterns were adopted as new applications of old forms: Gramaye used the allegory in a political way for a political theatrical event, the Joyous Entry. These developments opened the path for the next generation.

\section{The Third Generation - Consolidation, Renewal and Relocation (1600-1650)}

Around 1600 the separation of the Low Countries into the northern Republic of the United Provinces and the southern Spanish provinces had been consolidated. Although there were contacts between 'north' and 'south', ${ }^{145}$ both regions experienced their own individual development. At the turn of the century, Leiden University, founded in 1575, became a centre of renewal of Neo-Latin drama, just as Leuven University had been in the sixteenth century. In the southern provinces, the Habsburg Netherlands, the reign of the Archdukes Albert and Isabella from 1595 to 1621 after many years of troubles gave some relief to Flanders and a revival of cultural life during the Twelve Years' Truce. One of the main differences in the dramatic production between both regions is the fact that Jesuit playwrights continued to compose dramas on Joseph, Esther, Susanna, Judith and Tobias as examples of Christian virtues until the suppression of the order in $1773 .{ }^{146}$ Whereas Protestant poets were attracted to biblical stories in

\footnotetext{
${ }^{141}$ See the introduction by Verweij to his edition of the play. The full title runs: Tobias sive comice conscripta sacra Veteris Instrumenti Tobiae historia, praeter alia pietatis et virtutum documenta perspicuum quoddam coningalis continentiae et in rebus adversis patientiae exemplar proponens, iam primum iambico versu composita et in proscenium producta per Fratrem Petrum V laderaccum.

142 Vladeraccus, Tobias, ed. Verweij, pp. 47-48

143 Verweij, Het thema Tobias.

144 On the play, see Tournoy, 'De blijde Inkomst van Albrecht en Isabella te Leuven'.

145 See on these contacts esp. Porteman, 'Het Spaanse spook'.

146 Parente, Religious Drama and the Humanist Tradition, p. 83.
} 
which man was rewarded for his subordination of his soul to God's care, Catholic authors, especially the Jesuits who used theatre as a propaganda fidei and a weapon of Counter-Reformation, preferred hagiographical and historical themes in which they could show that man's obedience to the Church guaranteed his salvation.

In Leiden, Daniel Heinsius and the three years younger Hugo Grotius in mutual rivalry had set up a literary program to bring Latin tragedy, in the vein of Seneca, to a higher level. Both published a tragedy, in 1601 and 1602 respectively. Of course the invention of biblical tragedy and the history play had not been new, but Grotius with his tragedy on the fall of man and Heinsius with his drama on the assassination of William of Orange tried to set a new literary standard, and succeeded. In passing; they did not use drama for moral ends, as their forerunner had done, but for innovative variations of tragedy and to offer their country worthy pieces of literature. Grotius published his Adamus exul (Adam Exiled) in 1601, and Heinsius his Auriacus, sive Libertas saucia (Orange, or Liberty Wounded) the next year. Both wrote in imitation of Seneca and in rivalry with earlier plays. It is partly through their instigation, and through the changing times and fashions - for instance the growing interest in the tragedies of Seneca in general, that were seen as expressions of Stoic behaviour in times of trouble -, that now more tragoediae were written, and less fabulae and comoediae, although this seems to be a more gradual than an absolute change.

To write a tragedy, humanists had to cope with a serious problem of reconciling a tragic outlook in which the denouement was unhappy and poetic justice was not always apparent, with a Christian worldview in which God governs all, is always just and turns each misfortune into good fortune. Moreover, in Christian history world history fundamentally is irrelevant. Only a few events are important: creation, the fall, the redemption of mankind by Christ's birth, death and resurrection, in the past, and his Second Coming in the future. ${ }^{147}$ Viewed thus, tragedy hardly can be conceived. Tragedians had to cope with this problem, either by showing just one part of history that had a sad ending, ${ }^{148}$ or adapting their concept of tragedy in a Christian way. A third way was to emphasise the moral outlook of tragedy by showing, just as could be done in comedy, immorality as a sound of warning. We already saw Philicinus's solution by changing the tragic concept; we will encounter the same method in Heinsius, while some others chose the first way out. ${ }^{149}$ Another serious problem was their view that in Seneca's plays, the horrible outcome was precipitated by the characters' inability, or unwillingness, to control their passions, while in Christianity the passion of love is a virtue instead of a vice. In any case, the humanists readily stress the gravitas and sublimitas of Seneca's magniloquent style.

Hugo Grotius (1583-1645) tried his hand at the 'first history in Holy Writ containing a catastrophe, i.e. the fall of Man from the intact and happy state into this misery', thus applying

\footnotetext{
${ }_{147}$ Cf. Parente, Religious Drama and the Humanist Tradition, p. 47: 'Netherlandic humanists, eager to conjure up the horror and pssimism of Senecan tragedy, were forced by their choice of religious subject to expose the philosophical flaws of their model.

148 For instance, Grotius and Heinsius directed their readers' and spectators' attention to the philosophical differences between Crhistian and pagan response to religious tragedy, and they cheld taht sorrow was merely a temporary state of mind which would ultimately be alleviated by Christ's promise of justice and salvation, see Parente, Religious Drama and the Humanist Tradition, p. 55.

149 Another solution was to consider some biblical stories as 'tragic' or 'comic'. This is what Luther did with the Apocryphal books of Judith and Tobith: 'Denn Judht gibt eine gute, ernste, dapffere Tragedien, so gibt Tobias eine feine, liebliche, gottselige Comedien', Luther, Die gantze Heilige Schrifft Deudsch, ed. Volz and Balnke, 2, p. 1731. Quoted after Parente, Religious Drama and the Humanist Tradition, p. 26. Luther's observation coincided with the chronology of Isidorus of Sevilla who in his Etymologiae had tried to prove that Greek tragedy developed contemporaneously with the Apocrypha.
} 
the first solution. ${ }^{150}$ The edition was set up as a classical text, with an index rerum regarding theological, (ethical- and natural-) philosophical concepts in the play. This makes the play, written by a Protestant author, more universal, and Grotius could write to Justus Lipsius, who had gone to Catholicism and Leuven, that he had written his play for all Christianity. ${ }^{151}$ Grotius chose as his subject the fall of Adam and Eve, confining himself to this episode. Thus he implicitly criticized Macropedius in his almost epic treatment of the story. His play is a Senecan drama in the portrayal of the characters; Satan opens it with a soliloquy from the depths of hell. ${ }^{152}$

The same, one could say, was true for Daniel Heinsius (1580-1657). His drama Auriacus, sive Libertas saucia presented William of Orange, the pater patriae, as a Senecan virtuous hero, a new Hercules, who keeps his Stoic calm and intrepidly meets his death. ${ }^{153}$ His play was not the first one written on the theme: Panagius Salius or Toussain du Sel or Sailly from St. Omers had published a Nassovius: Tragoedia (1589). ${ }^{154}$ Here William of Nassau or William the Silent is portrayed as a rebellious heretic. A direct model for Heinsius was the Princeps Auriacus, sive Libertas defensa (1599) by the Delft conrector Caspar Casparius or Caspar Casparsen Ens (1568/1570-c. $1649 / 1652),{ }^{155}$ who is also known as the German humanist who translated Spanish picaresque novels into Latin. The play is clearly Senecan in style and structure, but the antagonist, 'Tyrannus' (i.e. the Spanish king Philip II, 1527-1598) is advised by the allegorical figures Eubulus ('Good Advisor') and Ahitophel (a wicked advisor from the Bible). ${ }^{156}$ In this respect it bears characteristics of Rhetoricians' drama, and perhaps there were contacts between members of the Delft Chamber and Ens. In any case, Ens's outlook on the murder is a Christian one: finally, God has been merciful to the Dutch by giving them William's son Maurice (1567-1625) to defend freedom.

While Ens's play in the outcome was happy, Heinsius's play is more tragic: liberty is wounded because of the protagonist's death. He seems to have written a timeless play in which William of Orange is a 'classical' Senecan hero, but there is something topical in it. A chorus of Flemish fugitives recites or sings odes - in a Senecan way composed stichically, not strophically - in which they deplore the loss of Flanders to the Spanish enemy. These choruses were written in the famous 'ten years' of Maurice's military successes, in which a discussion flared up whether 'the Dutch garden' had to be 'closed', or if the Spanish Netherlands should be reconquered. The play of Ens and especially that of Heinsius inspired others. The Leiden Rhetorician and captain in Maurits's army Jacob Duym (1547-1612/1616) wrote Het Moordadich Stvck van Balthasar Gerards (1606). ${ }^{157}$ In 1606 the discussion, now in the build-up to the Twelve Years' Truce (1609-1621),

\footnotetext{
150 Modern edition by Meulenbroek a.o. The quotation in this edition, p. 25: 'Historia est prima quae in Sacris occurrit Literis et Catastrophen habet, hominis ex integro felicique statu in hanc miseriam lapsus.' On Grotius's life, see Nellen, Hugo de Groot.

151 Grotius, Briefwisseling, no. 25, to Lipsius 01.11.1601: 'Toto orbi christiano haec [sacra poemata in quibus Adamus exul] vigilata sunt.'

152 See further Parente, Religious Drama and the Humanist Tradition, p. 56-58.

${ }^{153}$ Modern edition by Bloemendal. See also Bloemendal, 'Willem van Oranje: een Hercules op Leidse planken' and 'De dramatische moord op de Vader des Vaderlands'.

154 A modern edition, be it full of mistakes, by Vermaseren.

155 A recent edition was made by Bloemendal and Steenbeek. The full title runs: Princeps Auriacus, sive Libertas defensa. Tragoedia nova. On Ens, see, for instance, Killy, Literaturlexikon, 3, p. 266 (Kühlmann) and Ludwig, 'Zwei spanische Romane', pp. 131-42 and 174-75.

156 The discussion they have can be seen as a demonstration of what Altman, The Tudor Play of Mind, ch. 1, calls the modern 'explorative' against the medieval 'demonstrative' paradigm of theatre, or what Spies, "“Op de questye...”" called a quaestio disputata.

${ }^{157}$ Edition by Serrarens and Wijngaards. See on Duym Koppenol, 'Duym en de Leidse rederijkers'.
} 
became more fierce and Duym, born in Leuven, stuck to Maurice's side to continue war instead of negotiating peace. In the light of this discussion, William is presented as a martyr, who Duym implies - may not have died in vain. Another young officer in the prince's army and a Rhetorician, Gijsbert van Hogendorp (1589-1639), wrote his Truer-spel van de Moordt, begaen aen Wilhem by der Gratie Gods, Prince van Oraengien, etc to be staged in Delft, 1616; it was revived in The Hague and Amsterdam, where it marked the opening of the 'Nederdutysche Academie'. ${ }^{158}$ The Truer-spel is also a - free - remake of Heinsius's Auriacus. William is now portrayed as a ChristianStoic hero.

Heinsius's play was a direct inspiration for his relative Jacobus Zevecotius or Jacob van Zevecote (1596-1642) to write his Maria Stuarta, a Catholic play which he reworked into a Maria Graeca before publication. ${ }^{159} \mathrm{He}$ was born in Ghent, became an Augustinian priest like his fellow Johannes Chrysostomus Loots, and a professor of eloquence (i.e. Latin) at Ghent and Brussels, but when he converted to Protestantism, at the end of 1623 he fled to the northern countries, settled in Leiden for some years and ended up as a professor of eloquence and history at the 'Veluwsche Gymnasium' at Harderwijk in $1626 .{ }^{160}$ As a teacher, he wrote a tragedy Rosimunda (1621) and the above mentioned Maria Graeca (1623). After his move, he wrote dramas in Dutch: the tragedy Belech van Leyden (1626) and a tragicomedy, Ontstet van Leyden (1630,). Of the Maria Stuarta two manuscripts survive, but Zevecotius transformed the play on the Catholic Queen of Scots Mary (1542-1587), who was imprisoned for twenty years and then executed on orders from Queen Elisabeth I into a tragedy of a Byzantine princess, the wife of the Emperor Constantinus VII. He continued revising his play for the editions of 1625 and 1640, in order to improve the style and to adapt the text to his new faith. For instance, he altered the character Haeresis (Heresy) into 'Haeresis Iconoclastarum' (Heresy of the Iconoclasts), thus removing an allusion to Protestantism as a heresy. Of course some changes were as necessary as easy: changing Anglia into Graecia and the allegorical figure of 'Fides fugiens' became 'Fides coniugalis'. The adaptation of Heinsius's Auriacus remains apparent, in phraseology, ${ }^{161}$ but also in worldview: Mary, Queen of Scots, expresses the same acquiescent, Stoic-Christian view as William of Orange. Both plays end with a funeral lamentation to which the entire world and even the cosmos itself should join in. While Heinsius makes wounded Liberty express the mourning, Zevecotius gives this role to the Chorus and Fides (Faith) itself. ${ }^{162}$

Zevecotius's play had its forerunners. Stuarta tragoedia, written by the Catholic Neo-Latin poet and Benedictine priest Adrianus Roulerius or Adrien de Roulers (d. 1597) is one of the earliest tragedies on Mary Stuart's death. ${ }^{163}$ As a teacher of poesis at the Douai Abbey he wrote his Latin

\footnotetext{
158 A modern edition is made by Kossmann.

${ }^{159} \mathrm{It}$ is edited in a synoptic edition by IJsewijn, 'Jacobus Zevecotius: Maria Stuarta / Maria Graeca, Tragoedia'. The full title runs: Maria Graeca tragoedia, auctore P.F. Jacobo Zevecotio Ord. Erem. D. Ang. Exbibita in Coll. D.A. Bruxellis (Antwerp, Gullelmus a Tongris, 1623). In January 1612 Daniel Heinsius visited his relative, see ibidem, p. 258.

160 About the reasons for his conversion one may guess, but they may have had to do with the possibility to study, see IJsewijn, 'Theatrum Belgo-Latinum', pp. 95-96 on some letters which could indicate this.

161 Cf. the opening lines of Maria Stuarta: 'Rerum beate Genitor et magni potens / Dominator orbis, cuius aeternum tremit / Natura Numen [...]' with those of Auriacus: 'Rerum beate rector et magni parens / Natura mundi', both spoken by the protagonist.

162 See also Parente and Bloemendal, 'Character Criticism and the Humanist Tradition', on the relation between NeoLatin dramas on Mary Stuart and Vondel's Maria Stuart of Gemartelde Majesteit (1646).

163 Roulerius, Stuarta tragoedia, ed. Woerner; the full title runs Stuarta tragoedia sive Caedes Mariae serenissimae Scot[orum] Reginae in Anglia perpetrata (Stuart, a Tragedy, or the Murder of Mary, the Most Illustrious Queen of Scots, Committed in England); see also Woerner, 'Die älteste Maria Stuart-Tragödie'; Kipka, Maria Stuart, pp. 94-103; Phillips, Images of a Queen, pp. 193-95. The very first play was the Maria Stuarta tragoedia by Jean de Bordes, printed in Milan, 1589, and twice
} 
tragedy, which was performed by his pupils on 13 September 1593, only six years after the execution. In the vein of Seneca's plays - the tragedy has their five-act scheme - Roulerius makes the ghost of Henry VII appear from hell. Mary is a Christian and above all Catholic martyr, dying for her faith: 'The God who shed his blood for me, will see from heaven my blood shed for Him, and for the ancient rituals of the Church'. ${ }^{164}$

In Leiden itself, Heinsius and Grotius inspired their close friend Rochus Honerdus or Rochus van den Honert (1572-1638), councillor to the States of Holland, to write a tragedy on the story of Tamar: Thamara (1611). ${ }^{165}$ The subject was taken from Samuel 13 and Flavius Josephus, Jewish Antiquities, 7, 17. Honerdus does not revel in the lust of King David's son Amnon who rapes his half-sister, but analyses the sorrow of the father for his unwitting complicitiy in the affair. ${ }^{166}$ Therefore, he presents a sympathetic picture of Amnon the betrayer, showing him at first as a man struggling with his sinful passion who is really sick. The sympathetic, tender Tamar wants to help her brother. In the fourth act Tamar confesses to her other brother Absalom what has happended to her. David believes that it is God who in this crime punishes him for his adultery with Bathsheba. Therefore, he refuses to punish his son, and the tragedy ends with Absalom's vow to revenge his sister. This tragedy, too, is Senecan in style, structure and rhetoricalpsychological outlook. ${ }^{167}$ The tightness of the 'Leiden circle' under the aegis of the Leiden professor and philologist Josephus Justus Scaliger (1540-1609), who was born in France, may also be exemplified by the fact that Zevecotius dedicated his Maria Graeca to Honerdus. The 'members' of the circle sent each other their tragedies in order to discuss them before publication. ${ }^{168}$

Grotius and Heinsius themselves wrote other tragedies as well; Grotius composed Christus patiens (1608) and Sophompaneas (1635), Heinsius Herodes infanticida (written c. 1611, published 1632). The latter play became the reason for a serious quarrel between Heinsius and the French author Jean Louis Guez de Balzac on the mixture of pagan and Christian elements in a tragedy. ${ }^{169}$ With a fondness for horror in Senecan fashion, Heinsius had elaborated on the cruelties committed on behalf of Herod. In Holland, the town secretary of Amsterdam Daniel Mostaert (1592-1646) wrote an adaption of Heinsius's play in De Moord der Onnozelen (1639). Six years later, in 1645, the same play inspired Johann Klay (1616-1656) to write his Herodes.

produced before May 1590; see Phillips, 'Jean de Bordes' "Maria Stuarta tragoedia"” and Phillips, Images of a Queen, pp. 189-93. On Roulerius, see M.A. Nauwelaerts, Moderne Encyclopedie van de Wereldliteratuur, 8, p. 177; Roulerius, Maria Stuarta, ed. Woerner, pp. iii-xx; A. Roersch, Biographie Nationale de Belgique, 20, coll. 219-21.

164 Roulerius, Stuarta, 11. 811-14: 'Qui Deus pro me suum / Fudit cruorem, fundier pro se meum / Ecclesiaeque veteribus magnae sacris / Caelo videbit.'

${ }^{165} \mathrm{He}$ dedicates the play to Heinsius and Grotius, and in the preface 'To the reader', he openly acknowledges his debt to them.

166 See also Parente, Religious Drama and the Humanist Tradition, p. 59. Honerdus also wrote a Moses nomoclastes (Moses breaking the tables of the covenant) and an Auriacus, but both plays did not make it to the press and their manuscripts are now lost. As a matter of fact, Hooft admired him and wrote a laudatory poem for the Moses nomoclastes.

167 See also Bradner, 'Latin Drama', pp. 42-43.

${ }^{168}$ See a letter of Grotius to Heinsius, 26.02 .1608 (Grotius, Briefwisseling, 1, p. 97): 'Roge te per quicquid amas, [...] ut Tragoediam nostram, quam Christum Patientem inscribere Scaligero, Heroum maximo, visum est, perlegas quam diligentissime, emendes quam jliberrime, deinde quamprimum transmittas, ut ea quoque corrigam quae idem Heros admonuit.'

${ }^{169}$ See Bloemendal, 'Mythology ln the Early Modern Humanists' and rhetorician's stage in the Netherlands' and idem, 'Daniel Heinsius's Herodes Infanticida (1632) as a Senecan Drama'. Balzac focused on three main points: belief, appropriateness and coherence. 
In Grotius's third Sophompaneas Senecan - timeless - drama and topicality are combined. On the one hand he completed a kind a of 'trilogy of salvation', leading from the fall of man in Adam to Christ's passion in Christus patiens and a typology for Christ as a merciful ruler leading his people to salvation in the Joseph play. On the other hand the merciful rule of Joseph must serve as an example to the Dutch States General to grant its author, now exiled after his imprisonment in Loevestein castle because of his Remonstrant sympathies, a safe return to his home country. ${ }^{170} \mathrm{~A}$ third aspect of his drama is the strife for general peace and ancient religion that dominates Grotius's work in general. ${ }^{171}$

Johannes Narssius or Johan van Naarsen (1580-1637) was also a playwright from the Leiden circle. He first studied theology in Leiden at the 'Statencollege' and became a vicar. During the quarrels of the Twelve Years' Truce he, as a remonstrant, was removed from his position. Then he studied medicine, and became a physician in Dordrecht. In 1623 he fled the country and went to Sweden, where he worked as a court poet and historiographer for Gustaf Adolf II, and wrote there a panegyrical play on this king, Gustavus saucius (1628). ${ }^{172}$ The play, dealing with the campaigns of 1627 , is interesting because Narssius was personally acquainted with the people he was writing about. ${ }^{173}$

In spite of the literary activities of these alumni of Leiden University, the core of Latin drama now lay in the dominion of Albert and Isabella. There many tragedians were active: Nicolaus Vernulaeus in Leuven, Jacobus Cornelius Lummenaeus a Marca in Ghent, Father Joannes Surius S.J. at Mons and Father Jacobus Libenius S.J. at Malines. ${ }^{174}$ The Jesuits now dominated the scene, and although many of their plays were written anonymously, we do know some of their names. A token of this Jesuit activity appeared in 1634 in Antwerp; it was a compilation of tragedies by six Jesuit writers, Donatus, Stephonius, Malapertius, Petavius, Libenius, and Cellotius, entitled Selectae PP. Societatis Jesu tragoediae. It includes Bible plays, saints' plays and secular history plays.

As professors of rhetoric many Jesuit authors were obliged to write a play each year and have it performed by their students. Therefore, they used each other's plays and adapted them to other circumstances. So the history of Jesuit theatre is the history of performance, in multi-media shows, in which dances, songs and spectacle are used. Theatre was a kind of illustrated sermon.

One of the most prolific authors of this period is the professor of eloquence at the Leuven collegium 'The Porc', royal historiographer and president of the Luxemburg College Nicolaus Vernulaeus or Nicolas Vernulz (1583-1649). Between 1609 and 1648 he wrote fourteen history plays, and thus was responsible for the last upheaval of Neo-Latin academic drama at Leuven University. His works served the Habsburg dynasty and their Counter-Reformation politics; witness his first play, Gorcomienses sive fidei exilium (1610) on the martyrdom of 19 Catholic priests from the town of Gorcum hanged by the 'Watergeuzen' (Water- or Seabeggars) in Den Briel in 1572. The story is fully treated from a Catholic view. Vernulaeus also wrote dramas on martyrs from the early Church, such as Divus Eustachius sive fidei et patientiae triumphus (St Eustachius, or the Triumph of Faith and Patience, 1612), Divus Stanislaus: Tragoedia sacra (1618), and Conradinus et Crispus

\footnotetext{
${ }^{170}$ Eyffinger in his introduction to Sophompaneas, pp. 67-76.

${ }^{171}$ Eyffinger in his introduction to Sophompaneas, pp. 16-21.

172 Modern edition by Bolte, in Coligny, Gustaf Adolf, Wallenstein.

173 See the discussion by Raija Sarasti-Willenius in this volume, pp. \#-\#. On the reception of Dutch (Latin) plays in Sweden, see also Wrangel, De betrekkingen tusschen Zweden en de Nederlanden, Ch. 10.

${ }^{174}$ Jacobus Libenius (Jacques Libens, 1603-1678) wrote three Joseph plays: Iosephus agnitus (1639), Ioseph patri redditus (1656); Iosephus venditus (1634). Leuven library posesses the programme with an authograph dedication of a theatre play, Umfredus, that he had played at Ypres, 16 March 1624. See Ferd. Loise in BNB, 12, coll. 88-89.
} 
(1628); ${ }^{175}$ and tragedies on more recent historical events, for instance Henricus Octavus seu schisma Anglicanum (Henry VIII, or the English / Anglican Schism, 1624), ${ }^{176}$ Joanna Darcia, vulgo puella Aureliensis (Joan of Arc, in the Vernacular the Virgin of Orléans, 1629), and Fritlandus (1637). ${ }^{177}$ In Divus Eustachius the protagonist's rational response to misfortunes gained him eternal life. A second Job, Eustachius lost his property, saw his wife and children abducted and was condemned to death. Instead of showing undue emotions, he used his reason to extenuate them and thank God for these tests of his faith. He keeps, in a Stoic way, his calm and his patience. ${ }^{178}$ In Fritlandus Vernulaeus took as his subject the very recent death of Wallenstein in 1634, the Duke who wanted to become king of Bohemia. His contemporaries saw in his plays one dominant theme: vanitas, as is shown by the 'Censura' of the collected plays: 'These tragedies of the highly learned Nicolaus Vernulaeus show the vicissitudes of human fortune as a plaything of vanity'. ${ }^{179}$

The eight tragedies of the Benedictine Jacobus Cornelius Lummenaeus a Marca (c. 1580-c. 1628) are a special case. ${ }^{180}$ In the first place, he extended the possibilities of Senecan drama by taking their characteristics to an extreme. The choruses are an overwhelmingly dominant part of his drama, taking up to $70 \%$ of the text. ${ }^{181}$ Six of his plays treat Old Testament stories, among which Iephte, treating the famous story of the Judge Jephthah who took a rash vow that made him sacrifice his daughter (Judges 11, 30-40), Carcer Babylonius (Babylonian Captivity), on the capture of Jerusalem by the Babylonian King Nebukadnessar, the blinding of the Jewish King Zedekiah and the killing of his sons, ${ }^{182}$ and Amnon (1617) on the rape of Tamar by her half-brother Ammon (2 Samuel, 13), in which Lummenaeus could give vent to his enthusiasm for the violence of his model in the lust of Ammon. Another play treats the conversion of Saul into Paul (Saulus, Acts 9, 1-31), and a final one is the Dives Epulo, treating the famous story of poor Lazarus and the rich man, the 'glutton' or 'epulo' (Luke 16,19-31). While it is a highly allegorical play, associated more with Dutch Rhetoricians' farces or French sotties, than with tragedy, this play occupies a special position. For the other plays, it has been contended that they should be considered in the light of French humanist tragedy, such as those by Robert Garnier (1544-1590). ${ }^{183}$ In the preface to Carcer Babylonius Lummenaeus mentions Garnier, who had treated the same subject in his Les Juives (1583). In Iephte he took the same subject as the Scottish-French humanist George Buchanan (1506-1582) in his Iephthes sive votum (Jephthah, or the Vow, 1544).

His plays aimed at showing emotions, and the vicissitudines humanarum rerum, as the censor of Carcer Babylonius wrote. These vicissitudines may be considered the wish of the Catholic Church of a return of the northern provinces to true religion and Spanish dominion and a reunion of the Low Countries.

\footnotetext{
175 On this play, see Harmsen, 'Conradinus en de trits Vernulaeus, Oudaan, Smids'.

176 Translated into Dutch by Franciscus Guilelmus Zeebots, 1662; a modern edition of the play is made by Schuster.

177 Modern edition by Plard. See also Klecker, 'König Ottokars Glück und Ende in lateinischer Sprache'.

178 See, for instance: 'Ut in aequor undae sic miseriae in nos cadunt, / Succedit altera, cum prior nondum perit, / Et fortiorem sors resumit impetum / Cum saeviit: quis ergo finis, aut modus? / Tamen est ferundum, nam voluntas haec Dei est, / Et quia voluntas, quicquid obtingit placet.' Quoted after Parente, Religious Drama and the Humanist Tradition, p. 90, n. 100.

179 'Humanae sortis aleam uti vanitatis ludibrium exhibent hae eruditissimi domini Nicolai Vernulaei tragoediae', quoted after Klecker, 'König Ottokars Glück und Ende in lateinischer Sprache', p. 75.

${ }_{180}$ An extensive treatment of his plays in Gruijters, Am Eloquent Enigma Exposed. \#Voorlopige titel See also Parente, 'The Paganization of Biblical Tragedy', and Bloemendal, 'Paganization or Christianization?'.

181 See Janning, Der Chor im neulateinischen Drama, pp. 269-97, 'J. Cornelius Lummenaeus a Marca: der Chor als Hauptelement des Dramas'.

182 It was dramatized in 1616 by Malapertius, see below, p. \#.

183 Gruijters, An Eloquent Enigma, ch. 2, “Est est minoribus smaragdis sua gratia”: Lummenaeus' dramatic principles'.
} 
Jesuit drama was at its climax at this date. Its purpose still was to provide an edifying Christian alternative to the works of secular dramatists. The subject matter remained selected from the lives of saints or from the history of the early Church, especially during the age of persecutions under the Roman Emperors. As has been said, we know about only a portion of the plays, since most existed only in transitory manuscripts, in fragmentary periochae, and in momentary performances. Fortunately, some plays made it to the printing press, or their manuscripts are preserved.

The militant Jesuit Joannes David (1546-1613) wrote a play that was inspired by the parable of the five wise and the five foolish virgins (Matthew 25, 1-13). The virgins, however, are replaced by boys: Occasio arrepta neglecta: Huius commoda, illius incommoda (The Chance Taken or Missed: The Advantages of the First, the Disadvantages of the Second, 1605). ${ }^{184}$ It's an allegorical, very anti-Protestant play based on a likewise vigorous prose treatise he had written before, in which devils typical of medieval or Rhetoricians' drama play an important part.

Father Carolus Malapertius or Karel Malapert (1581-1630) was born in Mons, Hainault. ${ }^{185}$ As a Jesuit he was a teacher of mathematics and philosophy in Mons, Lorraine, Poland and Douai, and became a rector in Arras. During his residence in Poland, he wrote a tragedy Sedecias (1616), based on 2 Kings 24-25 and Flavius Josephus's Antiquitates Indaicae 10, 10 on the revolt of the Jewish king Zedekiah against Nebukadnezzar, king of Babylon, who is blinded and whose sons are killed. ${ }^{186} \mathrm{~A}$ typological reading of the play has been suggested, according to which King Zedekiah would represent the rebellious William of Orange and Nebukadnezzar the Spanish king Philip II. ${ }^{187}$ This can't be proved, but could suit the circumstances in the context of the Twelve Years' Truce and discussions about waging war or negotiating peace. In any case, he modelled his play like many of his confraters in the manner of the Roman tragedies attributed to Seneca, especially to Thyestes. The play enjoyed some success, and might have been performed perhaps eleven times between 1570 and $1739 .{ }^{188}$ It was included in the Selectae PP. Societatis Jesu tragoediae of 1634.

A fine example of a Jesuit playwright is Joseph Simons (Emmanuel Lobb, 1594-1671). ${ }^{189} \mathrm{He}$ was born in Portsmouth, studied theology and started his career as a teacher of poetry and rhetoric at the English College in St. Omer. His five tragedies were written for the school between 1623 and 1631: Vitus (1623), Mercia (1624), Thectistus (1624), Leo Armenius (1624/1629), Zeno (1631). Like many successful Jesuit school plays, these dramas circulated among the Jesuit colleges in manuscript by wandering teachers and enthusiastic visitors from other schools. ${ }^{190}$ Thus, they reached Switzerland and Italy, where they also had a favorable reception. His Latin plays contain many reminiscences of vernacular English (Elizabethan and Jacobean) drama. At first sight, his tragedies are just dramas on martyrdom: that of St. Vitus in the play with the same name, on that of the English martyr saints Ruffinus and Ulfadus in Mercia. But Simons paid more

\footnotetext{
184 See Van den Boogerd, Het jequïetentoneel, pp. 131-36.

185 See on him, Hernot, Malapert, Van den Boogerd, Het Jezuïetendrama, pp. 158-66, François de Vriendt 'Charles Malapert (1581-1630)', on http://www.pequet.com/webedition/malapert/malapert2.htm and www.dwc.knaw.nl/malapertius-carolus-1581-1630/.

186 Sedecias Tragoedia aliaque poemata Caroli Malapertii e Societate Jesu ad Serenissimum Vladislaum Poloniae principem (Duaci, typis viduae Petri Tela, 1624)

${ }^{187}$ Hernot, Malapert, pp. [24]-[29].

188 De Vriendt, 'Charles Malapert'.

189 See McCabe, An Introduction to the Jesuit Theater, pp. 133-43; Parente, Religious Drama and the Humanist Tradition, pp. 177-78; Parente, 'Tyranny and Revolution on the Baroque Stage', and the DNB, s.v. Lobb (Thomson Cooper). See also the chapter on Britain by Howard Norland, in this volume, pp. \#.

190 Parente, Religious Drama and the Humanist Tradition, p. 177.
} 
attention to the intrigues at court than other Latin playwrights, which is the most striking resemblance to English vernacular theatre. 'Religious differences between tyrant and martyr (pagan versus Christian) were almost completely disregarded; the enmity the martyr incurred arose not from his defense of Christ, but from his enemies' fears that they might lose their wealth and power because of the Christian's influence at court. ${ }^{191}$

Simons refrained from the ordinary militancy of Jesuit theatre and made the audiences attentive to the complexities of leading a Christian life in a deceitful world. ${ }^{192}$ His own or his order's aversion to revolution is mirrored in his plays, where the revolutionary is portrayed as problematic and the tyrants' victims as bearing the misfortunes with fortitude. For instance, in Leo Armenius the general Michael Balbus and his emperor Leo the Armenian are both represented as condemnable, and tyranny and revolution are abject alike. After all, Simons presented a pessimistic portrayal of history in which man's sole comfort is his faith in divine justice.

Simons himself was aware of his different approach to tragedy, as becomes clear from the 'Ad lectorem', which also points at the actual staging of his plays:

I should like briefly to remind you, dear reader, that these tragedies were designed primarily to be acted on stage. Accordingly, entr'actes were used instead of written choruses. In addition, the variety of characters and events is greater than was customary among classical playwrights. In other words, I had to bear in mind the taste of a new age, interpreting the rules of ancient tragedy rather freely. ${ }^{193}$

Another Jesuit, Father Joannes Surius (1554-1631) wrote twelve tragedies inspired by episodes from the Holy Writ and early Christianity. ${ }^{194}$ His heroes are in particular Sts. Augustine, Nicholas, Procopius, Ambrose and Vincent of Soignies, for instance, in his Domus evangelici patris familias (1617), presenting the good and the bad servant (Matthew 24, 45-51; Mark 13, 34-37; Luke 12, 42-48); Lucta carnis et spiritus in S. Augustini conversione (1617), in which some passages of the Confessiones are paraphrased as a fine exmaple for zealous young boys, Ambrosias (1618), B. Nicolai Maraei liberalis animus (1621), and S. Procopii conversio (1621). In his Drama iambicum de paenitentia Theophili (Drama in iambs on the penitence of Theophilus, 1621) Theophilus is saved through the intercession of the Virgin Mary (interveniente Beatissimae Virginis Mariae patrocinio singulari), as the title indicates. ${ }^{195}$ In his Magdalena Surius showed a gardener appearing to Mary Magdalene (John 20, 15). The lesson of the play is that 'only pure love can see Jesus in his true appearance, and each lingering is disastrous'. ${ }^{196}$ The international scope of Jesuit drama, as well as the volatility of

\footnotetext{
191 Ibidem, p. 178.

192 Parente, 'Tyranny and Revolution on the Baroque Stage', pp. 321-24.

193 'Paucis te monitum volo, Amice Lector, Tragoedias has actioni potissimum ac Theatro destinatas fuisse. Hinc pro Choris data Interludia. Hinc Personarum eventorumque varietas major quam quae apud Antiquos. Ita nimirum, Veteris Tragoediae legibus benignius explicatis, novi saeculi fastidio consulendum fuit.' Transl. by P.C. Fischer, S.J., quoted after McCabe, An Introduction to the Jesuit Theater, p. 133.

194 See on him Biographie Nationale de Belgique, 24, coll. 273-74 (Alphonse Roersch); Van den Boogerd, Het jezü̈etentoneel, pp. 170-221.

${ }^{195}$ See Proot, Het schooltoneel van de jezuïeten, 2, Spectacula Iesuitica Belgica Antiqua (SIBA), 2-25 Province Flandro-Belgica, p. 587, no. FB 63: Drama iambicum de pænitentia Theophili ecclesiæ orientalis regionis, nomine Adana secundæ Cilicum provincix Oeconomo \& impetrata suo de gravissimo peccato in Christum Dominum commisso, venia, interveniente Beatissimæ Virginis Mariæ patrocinio singulari, post quod tertio de infirmitate levi correptus in æde eiusdem Beatissimæ Virginis rebus suis ante bene dispositis beatus obijt 4. Februarij (Tournay: Adrianus Quinque, 1521).

196 Van den Boogerd, Het jequïetentoneel, pp. 172-73.
} 
borders are symbolized by this playwright. He was born in Béthune (in the region of Artois, now in northern France, then in the Netherlands); he worked mainly at Mons, and died in Tournai (both in the Belgian province of Hainault). Yet, Bradner listed him as one of of the 'three most considerable Jesuit dramatists' among the French playwrights. ${ }^{197}$

The theme - or better, the themes - from the story of Joseph in Genesis 37-50 were quite appealing for playwrights. We already noted the Joseph plays by Macropedius, Schonaeus and Grotius. For Jesuit dramatists they were appealing too. The bragging of Joseph might lead to advice on modesty, the intrigues of the wife of Potifar and Joseph's decency might serve as a summoning to chastity, the happy end in which Joseph and his brothers reconcile might point at mercy and grace. The Antwerp Father Jacobus Libenus or Jacques Libens (1603-1678) even wrote a Joseph trilogy: Iosephus venditus (Joseph Sold, 1634) Iosephus agnitus (Joseph recognized, 1639) and Iosephus patri redditus (Joseph Returned to his Father, 1656). ${ }^{198}$ The last play is now lost, but its subject is clear: the meeting of Joseph and his father Jacob in Egypt. The two extant plays are, as most of the Jesuit plays were, written in the style and structure of Seneca's tragedies. Joseph venditus dramatizes the story of Joseph's brothers throwing him into the pit and selling him to Midianites merchantmen (Genesis 37). Joseph, Libens tells us in the Prologue, is both a typological prefiguration of Christ and a moral model of virtue and trust in God. The tragedy aimed at arousing emotions, especially in the last scene, in which the audience saw father Jacob lamenting the supposed loss of his son and the chorus joining in the lament. The second play, Joseph agnitus treats the gradual recognition of Joseph by his brothers (Genesis 42-45). The play centres on an anagnorisis leading from misfortune to happiness. ${ }^{199}$ A 1755 Polish translation of one of them attests to the lasting popularity of Libenus's tragedies. ${ }^{200}$ Besides Libenus, no Jesuit from the Low Countries dramatized the story of Joseph, but its popularity is more attested by performances of the theme. ${ }^{201}$

The Jesuits were fond of the comedies by Plautus, both theoretically, as is attested by, among others, Strada, Pontanus and Neumayer, and practically, as can be concluded from several performances. ${ }^{202}$ However, they did not write many Plautine plays themselves. One of the exceptions for the Low Countries is Nicolaus Susius S.J. (1572-1619) who wrote a Pendularia (Play of the Gallows, 1620) for his pupils of the Jesuit school at Douai, where he was a professor of the poesis and rhetoric class. ${ }^{203}$ The title of the play is modeled after Plautus's Aulularia (Play of the Pot) and Mostellaria (Play of the Haunted House). The content, the form and the characters are all more or less Plautine: the young Pistoclerus ('Gambler', a character from Plautus's Bacchides) has

\footnotetext{
197 Bradner, 'The Latin Drama of the Renaissance', pp. 51-52.

198 See, for instance, Van den Boogerd, Het jezuïetentoneel, pp. 137-58. Besides these Joseph plays, he wrote two others, of which only the periochae survive and are preserved in teh University Library of Ghent: Umfredus Tragedie vertoont door de Jonckheyt der scholen van de Soc. Jesu tot Duynkercke Den (16) Maerte in het Jaer 1624, Tot Ypre, By Segher van den Berge and Bene qui latuit, bene vixit Alexius: In scenam dabitur a Rhetoribus, in aula Gymnasii Sco. Jesu Mechliniae 12 Martii 1635. The first Joseph play, Joseph venditus, appeared in the Selectae P.P. Soc. Jesu Tragoediae, vol. 2, pp. 108-35, the second one was probably written in 1638.

199 Van den Boogerd, Het jezü̈etentoneel, p. 154-55 points at similarities between Ioseph agnitus and Grotius's Sophompaneas, but Grotius's play is more a 'mirror of princes', showing the ideal statesman.

200 Ibidem, p. 139.

${ }^{201}$ Ibidem, p. 157 on performances of Joseph plays in the second half of the seventeenth century. In the first half of the century, Flandro- and Gallo-Belgian Jesuits staged the Josef theme at Colleges in Tournoy (1610, 1619), Maastricht (1619), Malines (1631, 1632, 1633), Ghent (1645), Antwerp (1647) and Brussels (1650).

202 Van den Boogerd, Het jezuietentoneel, pp. 166-67.

${ }^{203}$ Included into his Opuscula literaria: Poematia: Elegiae Marianae, Lusus Anacreontei, Drama Comicum (Antwerp: Heirs of Martin Nutius, 1620), pp. 241-75; see on the play Van den Boogerd, Het jezuietentoneel, pp. 166-70.
} 
to study under the slave and pedagogue Lydus ('Lydian'), but instead of studying, they go to drunken friends of Pistoclerus. Both pupil and pedagogue get drunk. Therefore, all are awaiting the gallows. But in the end they reconcile and are saved. That such a theme was deemed inappropriate for a Jesuit becomes clear from a letter, written by the general to the provincial of the Gallo-Belgian Province, 30 October 1621. He considered the play to be meek, almost sensual, unworthy of a Jesuit. ${ }^{204}$ Tragedy, then, was the Jesuit genre, and more specifically Senecan tragedy. Comedy was for the 'others'.

A curious play was written by Franciscus van den Enden (1602-1672. ${ }^{205}$ Born in Antwerp, he was sent to an Augustinian school, and became a Jesuit, but he was dismissed from the Order for unclear reasons. He married and went to Amsterdam, where he opened a Latin School. In 1657 he wrote and staged an allegorical play, Philedonius of Lusthart (He who loves to please).In the same period Spinoza was a pupil of Van den Enden's school. Vanden Enden is considered as a protospinozist. The play, on the career and the conversion of a libertine young man, consists of three acts, in which the man, Philedonius, has a dialogue with a moral-allegorical figure, Prudentia, a religious-allegorical one, Misericordia, and an eschatological-allegorical figure, Somnium. Its motto - and starting point - were 'the words of the Wise man' (Jezus Sirach 7,36): 'Remember the ends of your life in all your works, and you will never sin'. The ends are death, judgment, heaven and hell. The interpretation of the play is not univocal: it is called 'very pious and of a good moral purport', or 'the natural history of human wisdom, the mind as an automatically improving reflector on what goes on in one's heart', 'a comedy that refers esoterically to a saying by Jesus ben Sirach while an oppostie hermetic-alchemic subtext is developed esoterically' and 'a subtle work of crypto-Jesuit and anti-Jansenist apologitcs' ${ }^{206}$ Whatever it may be, the play was performed at the Amsterdam City Theatre on January 13, 1657, and was reprised several times, and also a shortened reworking of the play in Dutch was published.

\section{Epilogue}

In retrospective, Latin theatre of the Low Countries saw its beginnings in the first decade of the sixteenth century, in which the humanist comedies and fabulae sacrae prevailed: dramas of biblical and other religious subjects such as the Everyman theme. The plays were written for the Latin schools, and their direct source of inspiration seems to be the University of Leuven, the pedagogies and the Collegium trilingue. Most of the authors had studied there. Besides religious dramas, they also wrote Shrovetide plays and other farces. In the 1550's important playwrights of this generation published their 'collected plays' (Macropedius's Omnes fabulae, 1552-1553), stopped writing (Brechtus, 1548) or died (Crocus, 1550). The next generation continued writing plays, but expanded the way they treated the subject matter, often by adding a more thoroughgoing Stoic worldview (Schonaeus). In the years between 1550 and 1600 the Low Countries became more and more divided into a northern, Protestant part of the Republic of the United Netherlands and a southern one, consisting of the provinces that returned to Catholicism.

\footnotetext{
204 Van den Boogerd, Het jezü̈etentoneel, p. 170.

205 See on Van den Enden: Mertens, 'Enden',on the play Proiette, Philodonius, containing an edition with a Latin translation, pp. 182-289, On both author and play: http://telenet.be/fvde (a site made by Frank Mertens) [accessed 13 Jan. 2011]. See also Korsten, 'Mundus dramaticus'.

206 See users.telenet.be/fvde, 'Works', nn. 6 and 7.
} 
Especially in the southern provinces, the Jesuits set their feet and started performing moralizing and theologizing theatre plays. It is in this development that also plays on saints' lives were written and staged.

The turn of the century saw the rise of history plays, dealing with events that took place on their own soil, such as the assassination of William of Orange, the martyrs of Gorcum, or of Catholic subjects such as the death of Mary Stuart. Now the imitation of the plays attributed to Seneca prevailed, instead of the imitation of Plautus and above all Terence, witnessed in the previous generations. Especially in the southern provinces, Jesuit drama gained more and more importance. The development from comedy to tragedy - of course not in an absolute sense had to do with the growing importance of university drama, especially in the northern part after the foundation of Leiden University in 1575.

All of this should be seen in the light of the (relative) absence of a court culture in the Low Countries. Of course, in Brussels a court and a court culture existed, and the royal entries can be considered as such, but as a whole, court culture is meagre, particularly in the northern provinces, where the stadtholder served his country under the guidance of the States General. Among other aspects, it is this feature that laid more stress on school and university as places of Latin drama.

However, neither these schools nor these universities were islands on their own: there were contacts with local authors in the vernacular, themes, motifs or formal features of Rhetoricians' plays were taken over, Latin plays were translated into vernacular languages. Latin drama in the Low Countries was a lively, respectable genre that in some cases resembled vernacular drama, reacted to it, or aroused reactions.

After the 1650's Latin drama did not entirely disappear, but fewer and fewer new plays were written, and fewer old plays were staged. This may have occurred because of the growing rejection of theatre in general by the Calvinist ministers in the Dutch Republic, but also because of the decline of the Latin school itself. And that had to do with the decline of the Latin language, in favour of the vernacular. 


\section{Appendix \\ MAIN AUTHORS}

BRECHTUS, Levinus or Brechtanus (1515-1560), a Friar Minorite in Leuven who was born in Antwerp, wrote his play Euripus for the Leuven College 'The Falcon', and had it performed on 1 July, 1548. The play, which was inspired by Rhetoricians' theatre, was printed in 1549 and had a European success, especially among Jesuits.

Works

Euripus (1549), ed. Rädle, Lateinische Ordensdramen, pp. 3-276.

Studies

Valentin, 'Aux origines du théâtre Néo-latin'; idem, Les jésuites et le théâtre, pp. 202-04; Wimmer, Jesuitentheater, pp. 106-17; Rädle, 'Aus der Frühzeit des Jesuitentheaters'; id. 'Die Bühne des Euripus'.

Crocus, Cornelius or Cornelis Croock (ca. 1500-1550) was born in Amsterdam. A Roman Catholic Minorite priest, he was Rector of two respective Latin schools in Amsterdam. His Ioseph was staged in Amsterdam in December 1535, published in Antwerp in 1536, and had a great success. Just before his death, he entered the Jesuit Order.

Works

Ioseph (1535), ed. Bloemendal.

\section{Studies}

Kölker, Alardus Aemstelredamus en Cornelius Crocus; NNBW, 3, pp. 267-68 CE 1, p. 362; Kearns, 'Pagan Wisdom, Christian Revelation'; Spies, 'A Chaste Joseph for Schoolboys'; Lebeau, Salvator Mundi, pp. 301-13 and 1003-08.

GNAPHEUS, Guilielmus, Willem de Volder or Van de Voldersgraft, or Fullonius (1493-1568) was born in The Hague and became a Rector of the Latin School there. For his Lutheran writings he had to flee to Prussia (in Poland). His most famous work was, and is, the play on the theme of the Prodigal Son, Acolastus, that was staged and printed all over Europe; his Morosophus has as its subject a flute player, Morus, who wants to be an astronomer and calls himself Morosophus. Hypocrisis is a satire on the hypocrisy of the Roman Catholic Church. Triumphus eloquentiae is more of a dialogue.

Works

Acolastus (1529), ed. Bolte; ed. Minderaa; ed. Atkinson; Morosophus (1541); Hypocrisis (1544); Triumphus eloquentiae (1541). 
Demoed, Wie van gevaar houdt, ead., 'Theatre in Court'; 'The Morality of Hypocrisy'; 'Stultitia on Stage'; Rädle, 'Theatralische Formen', pp. 280-88; id., 'Zum dramatischen Schaffen des Gulielmus Gnapheus im preussischen Exil'; Macardle, The Allegory of Acolastus.

Grotius, Hugo or De Groot (1583-1645) a Dutch jurist and politician, who was sent to prison for his religious beliefs and went into exile. Together with Daniel Heinsius he had studied in Leiden with Joseph Scaliger; both friends set up a literary reform, for which they wrote classical tragedies in the style of Seneca. Grotius's three dramas can be considered as a trilogy.

Works

Adamus exul (1601), ed. Meulenbroek; Christus patiens (1608), ed. Meulenbroek and Eyffinger; Sophompaneas (1635), ed. Eyffinger.

Studies

Rädle, 'Hugo Grotius als Dramatiker', Eijffinger, 'The Fourth Man', Nellen, Hugo de Groot.

HeINSIUS, Daniel or Heins (1580-1655), was the son of Flemish refugees who went to Leiden, where he studied at the artes faculty. He was librarian, Professor of poetry, and Professor of Greek at Leiden University, royal historiographer of Gustaf Adolf of Sweden, a poet in Latin and Greek and a theologian. In competition with Hugo Grotius, he wrote two tragedies in Senecan style, Auriacus, sive Libertas saucia (1602) and Herodes infanticida (written 1611, published 1632). He also wrote an influential treatise on tragedy, De tragoediae constitutione (1611).

Works

Auriacus, sive Libertas saucia (1602), ed. Bloemendal; Herodes infanticida (1611/1632).

Studies

Becker-Cantarino, Daniel Heinsius; Meter, The Literary Theories of Daniel Heinsius; Lefèvre and Schäfer, Daniel Heinsius.

HolONiUs, Gregorius or Grégoire de Hologne (1531?-1594) was born in Liège. He was an instructor at the gymnasium Bartholomaeanum (St. Barthelemy's) in his native city and a tutor of the three sons of Charles V's general Charles de Berlaymont. He wrote three martyr plays on St. Catherine of Alexandria, St. Lambert and St. Laurence. They were performed in Liège and printed in Antwerp; its choral songs are set to music by the composer Joannes Laetrius or Petit Jan de Latre (ca. 1505-1569).

Works

Catharina (1556); Lambertias (1556); Laurentias (1556)

Studies

Parente, 'Counter-Reformation Polemic and Senecan Tragedy'. 
LAURIMANUS, Cornelius or Lauwerman (ca. 1530-1573) was a pupil of Georgius Macropedius, who earned fame as a dramatist. After he had studied in Leuven, he was a Utrecht rector scholae and playwright, who remained a Roman-Catholic in a time that Protestantism spread in the Netherlands. His Latin plays were meant to be a bulwark against 'heresy'. Lauriman(n)us wrote his plays about the Old Testament books of Esther and Exodus; the Miles christianus, on the Christian soldier, is an allegorical play.

Works

Esthera regina (1560); Exodus sive transitus maris rubri (1562); Miles christianus (1565); Thamar (s.d.); Tobias (s.d.); Nabath (s.d.).

\section{Studies}

Bloemendal, 'Cornelius Laurimanus als Dramatiker'.

LiBENUS, Jacobus or Jacques Libens (1603-1678) was a Jesuit playwright who was born in Antwerp and taught moral theology. He wrote three plays on the Joseph theme, of which the first one was included in the Selectae P.P. Soc. Iesu Tragoediae. The plays were written for the Jesuit schools in Antwerp and Mechelen.

Works

Iosephus venditus (1634); Iosephus agnitus (1639); Ioseph patri redditus (1656).

\section{Studies}

Lummenaeus A MarcA, Jacobus Cornelius or De Marcke (ca. 1580-ca. 1628) was a Ghent Benedictine priest and a good friend of the humanist Erycius Puteanus. He wrote his dramas during the last twenty years of his life. Their main characteristic is the overwhelming length of the choral songs, bringing this feature of Senecan drama to its extreme.

Works

Abimelechus (1622); Absalon (1624); Amnon (1617); Anastasius (uned.); Bustum Sodomae (1615); Carcer Babylonius (1610); Jephte (1608); Sampson (1623); Saul (1628); Sedechias (1628)

\section{Studies}

Gruijters, An Eloquent Enigma; Parente, 'The Paganization of Biblical Tragedy'.

MACROPEDIUS, Georgius or Joris van Lanckvelt (1487-1558) was born in Gemert, near Den Bosch, and became rector respectively of the Latin schools in Den Bosch and Utrecht. For his pupils, he wrote grammar books, and twelve plays: farces, biblical plays and comedies on school 
life and peasants. His plays, and especially his Hecastus, were staged throughout Europe and translated.

Works

Adamus (1552); Aluta (1535), ed. Bolte; ed. Bloemendal and Steenbeek; Andrisca (1538), ed. Tak; ed. Leys; Asotus evangelicus (1537), ed. Puttiger; Bassarus (1540), ed. Engelberts; Hecastus (1539), ed. Bolte; ed. Verschelde; ed. Dammer and Jeßing; Hypomone (1553); Iesus scholasticus (1556); Iosephus (1544); Lazarus mendicus (1541); Petriscus (1536); Rebelles (1535), ed. Bolte.

\section{Studies}

Giebels and Slits, Georgius Macropedius; Macropedius, Verzameld toneel, ed. Bloemendal; Best, Georgius Macropedius; Bloemendal, The Latin Playwright Georgius Macropedius; Macropedius, Koren en liederen, ed. Dekker.

SchonaEus, Cornelius or Cornelis Schoon (1540-1611) was born in Gouda. He studied artes in Leuven; he was a schoolmaster and Rector of the Latin school at Haarlem. He wrote thirteen Biblical plays, three farces and a lottery play (Fabula comica). His Dyscoli is an imitation of Macropedius' Rebelles. His fame and authority are illustrated by the fact that after Haarlem became a protestant city, Schonaeus, a true Roman-Catholic, could stay rector of the school.

Works

Ananias (1602); Baptistes (1603); Cunae (1596), ed. Van de Venne; Daniel (1596); Dyscoli (1603), ed. Van de Venne; Fabula comica (1607); Iosephus (1592), ed. Bloemendal and Groenland; Iuditha (1592); Naaman (1572); Nehemias (1570); Pentecoste (1602); Pseudostratiotae (1592), ed. Van de Venne; Saulus conversus (1570); Susanna (1599); Tobaeus (1569), ed. Verweij; Triumphus Christi (1599); Typhlus (1602); Vitulus (1596), ed. Van de Venne.

Studies

Van de Venne, Cornelius Schonaeus Goudanus.

SimONS, Joseph or Emmanuel Lobb (1594-1671) was born in Portsmouth. After he studied theology he went to Flanders as a teacher of poetry and rhetoric at the Jesuit College of St. Omer. He wrote five tragedies.

Works

Vitus (1623), Mercia (1624), Thectistus (1624), Leo Armenius (1624/1629), Zeno (1631).

\section{Studies}

McCabe, An Introduction to the Jesuit Theater, pp. 133-43; Parente, 'Tyranny and Revolution on the Baroque Stage', DNB, s.v. Lobb (Thomson Cooper); see Simons, Jesuit Theater Englished. 
SURIUS, Johannes (1554-1631), a Jesuit author of twelve tragedies with subjects taken from the Bible and early Christianity. He was born in Béthune, worked at Mons and died in Tournai (in what is now Belgium).

Works

Absalonis moesta catastrophe (1621); Ambrosias (1618); B. Mariae Magdalenae erotici threni (1617); B. Nicolai Maraei liberalis animus (1621); Coningium B. Madelgarii cum B. Waldetrude (1621); Domus evangelici patris familias (1617); Drama iambicum de paenitentia Theophili (1621); Iovinianus (1618); Lucta carnis et spiritus in S. Augustini conversione (1617); S. Procopii conversio (1621); Scientissimi custodis gubernatorisque reipublicae perpendiculum (1621); Ulyssias (1621).

Studies

BNB, 24, coll. 273-74 (Alphonse Roersch); Van den Boogerd, Het jezü̈etentoneel, pp. 170-221.

Vernulaeus, Nicolaus or Nicolas de Vernulz (1583-1648) was born in Luxemburg and studied in Trier and Cologne. He became respectively Professor of Rhetoric, Professor of Eloquence and Professor of Latin in Leuven. He wrote fourteen historical tragedies: martyr plays and plays on tyranny; some plays treat events from very recent history.

\section{Works}

Conradinus (1628); Crispus (1628); Divus Eustachius (1612); Fritlandus (1637), ed, Bolte, ed. Rousseau and Plard; Gorcomienses (1609); Henricus Octavus (1624), ed. Schuster; Hermengildus (1656); Joanna Darcia (1629), ed. De la Tour; Lambertus (1656); Maximus (1630); Ottocarus Bohemiae rex (1626); Theodorus rex Italiae (1623); Thomas Cantuariensis (1631).

\section{Studies}

ADB, 39, pp. 628-32 (Bolte); Klecker, 'König Ottokars Glück und Ende’; Schuster, 'The History of the Louvain Theatre'; Depuydt, Nicolaus Vernulaeus.

Zevecotius, Jacobus or Van Zevecote (ca. 1596-1642) was born in Ghent. He studied philosophy and law and became an Augustinian monk. He left the Southern Provinces and went to the Northern part of the Low Countries where he became Professor of History and Eloquence in Harderwijk. He wrote tragedies both in Dutch and in Latin. He reworked his Maria Stuarta, which was inspired by Heinsius's Auriacus, into a Maria Graeca.

Works

Esther (1623); Maria Graeca / Maria Stuarta (1623/1625), ed. IJsewijn; Rosimunda (1621, 1625).

Studies

IJsewijn, 'Maria Graeca / Maria Stuarta'. 